\title{
De winsten van zorginstellingen
}

\author{
Jeroen Suijs \& Harrie Verbon ${ }^{*}$
}

Ruim tien jaar geleden werd in Nederland, met de nieuwe basisverzekering, marktwerking in de zorg op grote schaal ingevoerd. Het idee was dat concurrentie tussen zorgverzekeraars en tussen aanbieders van medische zorg zou leiden tot een vergroting van efficiëntie en daardoor tot lagere kosten van de zorg. Bij de zorgverzekeringen concurreren verzekeraars om klanten, met hun premies en het zorgverzekeringspakket als belangrijkste instrumenten. Marktwerking kan hier verantwoord zijn omdat klanten relatief eenvoudig aan informatie kunnen komen over premies en de inhoud van het zorgverzekeringspakket van de zorgverzekeraars. Bovendien is er voldoende keuze wat het aantal verzekeraars betreft.

Bij zorginstellingen echter, waar de cliënten vaak kwetsbare mensen zijn met chronische lichamelijke of geestelijke beperkingen, geldt dat niet. Cliënten kiezen vaak niet bewust voor een zorginstelling en worden als cliënt snel afhankelijk van hun zorgaanbieder voor het op orde houden van hun leven. Dit zal zeker ook het geval zijn als de zorgaanbieder gratis of tegen een vergoeding voor woonruimte voor de cliënt zorgt. ${ }^{1}$ De desbetreffende cliënten hebben vaak geen idee wat hun rechten op zorg zijn en hoeveel zorg er feitelijk aan hen besteed wordt in tijd en/ of geld. Het is duidelijk dat concurrentie dan niet werkt en marktwerking zelfs kan leiden tot misbruik van zorggelden.

Bij marktwerking is het maken van winsten of verliezen onvermijdelijk en zijn winsten noodzakelijk voor het aanleggen van buffers voor slechte tijden. Volgens de accountantsorganisatie Ernst \& Young (hierna: EY) neemt in meerdere deelsectoren van de gezondheidszorg het rendement af, zodat er 'weinig mogelijkheden zijn om buffers op te bouwen, of te kunnen investeren en innoveren en er een sterke focus ligt op de financiële bedrijfsvoering' (EY, 2016, 4). Het overheidsbeleid waarbij bezuinigingen in de zorg een dominant patroon vormden, zal dus impliceren - zo is de suggestie van EY - dat niet de kwaliteit van de zorgverlening, maar gezonde financiën de drijfveer van zorginstellingen wordt.

Anderzijds zijn er in de Kamer diverse gevallen besproken van zorgbedrijven waar directeuren van zorginstellingen excessief hoge inkomens (eventueel inclusief dividendinkomens) verdienden, gefinancierd uit zorggelden, terwijl de kwaliteit en/of kwantiteit van de zorg achterbleven. ${ }^{2}$ Het gemiddelde beeld, zoals dat door EY wordt geschetst, wijkt kennelijk af van wat sommige individuele zorgbedrijven weten te realiseren. Daarom kijken wij in dit artikel niet alleen naar de gemiddelde waarden van financiële indicatoren, zoals winsten, maar we maken ook een

* Prof. dr. Jeroen Suijs is hoogleraar financial accounting aan de Erasmus Universiteit in Rotterdam. Prof. dr. Harrie Verbon is hoogleraar openbare financiën aan de Universiteit van Tilburg. 
Tabel 1 Specificatie datasets

\begin{tabular}{lll}
\hline & DigiMV 20 I4 & DigiMV 20 I5 \\
\hline Aantal zorginstellingen & 2.376 & 2.195 \\
Geen financiële data beschikbaar & 965 & 796 \\
Omzet <= & 13 & 14 \\
Totale activa <= & 10 & 10 \\
Verlieslatende ondernemingen & & \\
Dataset I & 1.387 & 1.375 \\
Ziekenhuizen & 109 & 94 \\
Geen bv of stichting & 73 & 117 \\
Dataset 2 & 1.206 & 1.164 \\
\hline
\end{tabular}

onderverdeling naar de omvang en de organisatievorm (bv of stichting) van de zorgbedrijven.

De vragen die wij ons stellen zijn derhalve of, ten eerste, het gemiddelde, gematigd sombere beeld dat EY schetst van de zorgsector als geheel door ons ook wordt gevonden en, ten tweede, of in de onderscheiden subsectoren verschillende conclusies kunnen worden getrokken ten aanzien van de winstgevendheid van zorgbedrijven. De gegevens die we gebruiken, zijn afkomstig van de dataset DigiMV 2014 en 2015 op de website www.jaarverslagenzorg.nl. 2015 was het jaar dat een groot deel van de langdurige zorg werd gedecentraliseerd naar de gemeenten. Een groot deel van de hier beschouwde zorg werd in 2014 nog gefinancierd uit de Algemene Wet Bijzondere Ziektekosten (AWBZ). Het is daarom interessant om naast 2014 ook het jaar 2015 te beschouwen, omdat wij dan kunnen vaststellen of de decentralisatie de winstgevendheid van de zorginstellingen al heeft beïnvloed. In de tekst worden de resultaten voor zowel 2014 als 2015 getoond.

Wij hebben alleen de zorgondernemingen in beschouwing genomen die actief zijn in de segmenten geestelijke gezondheidszorg (GGZ), maatschappelijke opvang/ vrouwenopvang (MOVO), gehandicaptenzorg (GHZ), verpleging, verzorging en thuiszorg (VVT), kraamzorg en jeugdzorg. ${ }^{3}$ Verder zijn de eenmanszaken, maatschappen en vof's (vennootschappen onder firma) buiten beschouwing gelaten. De reden hiervoor is dat het inkomen van maten en vennoten uit de winst betaald wordt; zij ontvangen geen salaris van de onderneming. Hetzelfde geldt voor de eigenaar van een eenmanszaak. Alle zorgondernemingen waarvan de benodigde data niet in de DigiMV-dataset zijn ingevuld, zijn buiten beschouwing gelaten. Dit levert uiteindelijk voor 2014 een dataset van 1.206 zorgondernemingen op (in DigiMV 2014 staan in totaal 2.376 zorgondernemingen), terwijl het voor 2015 om 1.164 zorgondernemingen gaat (van in totaal 2.195). Zie tabel 1 voor een specificatie.

Vanuit bedrijfseconomisch oogpunt kunnen we op meerdere manieren naar de financiële prestaties van zorginstellingen kijken. EY (2016) richt zich in zijn rap- 
port op de nettowinstmarge van de zorginstellingen. De nettowinstmarge is de nettowinst uitgedrukt als percentage van de omzet. Nettowinst is dat wat onderaan de streep overblijft voor de eigenaren van de zorginstelling en is gelijk aan de omzet minus operationele en financiële kosten en winstbelastingen. Belangrijk in dezen is dat nettowinst beïnvloed wordt door de kapitaalstructuur van de zorginstelling, dat wil zeggen de wijze waarop de zorginstelling met eigen en vreemd vermogen is gefinancierd. Financiering met vreemd vermogen heeft een hefboomwerking op het rendement op het eigen vermogen en drukt de nettowinstmarge. Een financiële maatstaf die de kapitaalstructuur buiten beschouwing laat, is het rendement op het totale vermogen. Deze maatstaf beschouwt de som van winsten en de rente op leningen als een beloning voor het beschikbaar stellen van vreemd en eigen vermogen. Het is daarbij in feite niet relevant of de activa beschikbaar zijn gesteld door de eigenaren of door externe geldschieters. In zekere zin zijn deze twee vermogenscategorieën communicerende vaten die niet goed te scheiden zijn. Het rendement op het totale vermogen is gelijk aan de nettowinst plus rentekosten, uitgedrukt als percentage van het totale geïnvesteerde vermogen. Hierbij wordt in feite gekeken naar de totale financiële prestatie van de zorginstelling, ongeacht wie aan de financiering van de instelling heeft bijgedragen, de eigenaar of de verstrekkers van vreemd vermogen. Naast de nettowinstmarge zullen we daarom ook het rendement op het totale vermogen van de instellingen als indicator voor de financiële prestaties van zorginstellingen presenteren. Deze maatstaf geeft naar onze mening een beter beeld van de opbrengsten en kosten voor het aanbieden van zorgactiviteiten.

Een van onze bevindingen is dat bij kleine zorgbedrijven, met een omzet tot ongeveer 1 miljoen euro, relatief hoge nettowinsten worden behaald, tot soms meer dan 40-50 procent van de omzet. Ook als wij het rendement op het totale vermogen als indicator van de winst nemen, geldt deze conclusie. Dit rendement bedraagt soms meer dan 100 procent van de totale activa. In enkele gevallen hebben deze relatief hoge winstpercentages geleid tot hoge dividenduitkeringen voor de eigenaren van zorgbedrijven, die soms tevens lid waren van de directie. Deze bevinding roept de vraag op of de overheid geen striktere regels moet voorschrijven over de besteding van winsten. De Wet toelating zorginstellingen kent nauwelijks beperkingen bij het toelaten van zorginstellingen met een winstoogmerk (zie wetten.overheid.nl). ${ }^{4}$

Daarnaast blijkt een deel van de kleine zorgbedrijven ook ongekend hoge verliezen te lijden van soms meer dan 100 procent op het totale vermogen. Dergelijke verliezen zouden in de marktsector zonder meer tot faillissementen leiden, waarna de desbetreffende bedrijven van de markt zouden verdwijnen. Hoewel wij dit niet diepgaand onderzocht hebben, lijkt maar een deel van deze verlieslijdende zorgbedrijven van de zorgmarkt te verdwijnen. Het overige deel blijft 'zelfstandig' opereren ${ }^{5}$ of gaat op in een andere zorginstelling, waarna er geen zicht meer is op de financiële prestaties van het verlieslijdende zorgbedrijf.

Zoals eerder vermeld, is het jaar 2014 het laatste jaar dat de langdurige zorg voor het grootste deel onder de AWBZ viel. Vanaf 2015 valt een groot deel van deze zorg onder de Wet maatschappelijke ondersteuning 2015 en zijn de gemeenten grotendeels verantwoordelijk voor de uitkomsten in de sector. Dat betekent dat 
het financieel toezicht op de zorgaanbieders voor een groot deel ook is verschoven naar de gemeenten. In 2014 lag dit nog bij het rijk, al hebben de Inspectie Gezondheidszorg (IGZ) en de Nederlandse Zorgautoriteit (NZa) nog een toezichthoudende taak behouden. De IGZ ziet vooral toe op de medische aspecten van de geleverde zorg; de NZa ziet toe op de juiste wijze van declareren. Behalve bij de gemeenten ligt er ook een toezichthoudende taak bij de raden van toezicht van zorginstellingen. Deze blijken niet altijd objectief genoeg te zijn om deze taak geloofwaardig uit te kunnen oefenen. In het nieuwe stelsel (vanaf 2015) zal dus het grootste deel van het financiële toezicht bij de gemeenten komen te liggen, waarbij de gemeentelijke accountants en de gemeentelijke rekenkamers naar verwachting een belangrijke rol zullen spelen. Uit onze gegevens blijkt echter dat in 2015 nog geen grote veranderingen zijn opgetreden in het algemene beeld van de winst- of verliesgevendheid van instellingen. We komen hier in onze afrondende paragraaf op terug.

\section{De winsten per sector: voor bv's en stichtingen}

In tabel 2a worden voor ziekenhuizen, revalidatiecentra, de bovengenoemde sectoren en voor alle instellingen tezamen respectievelijk het aantal instellingen, de omzet, de nettowinst en de nettowinstmarge weergegeven. In tabel $2 \mathrm{~b}$ worden, naast het aantal instellingen, de totale activa, de nettowinst en het rendement op het totale vermogen weergegeven. In beide tabellen worden de gegevens gepresenteerd voor alle en voor alleen de winstgevende zorgondernemingen. Daarnaast wordt in beide tabellen ook de winstmarge respectievelijk het rendement op het totale vermogen voor de 10 procent best presterende ondernemingen gegeven. 


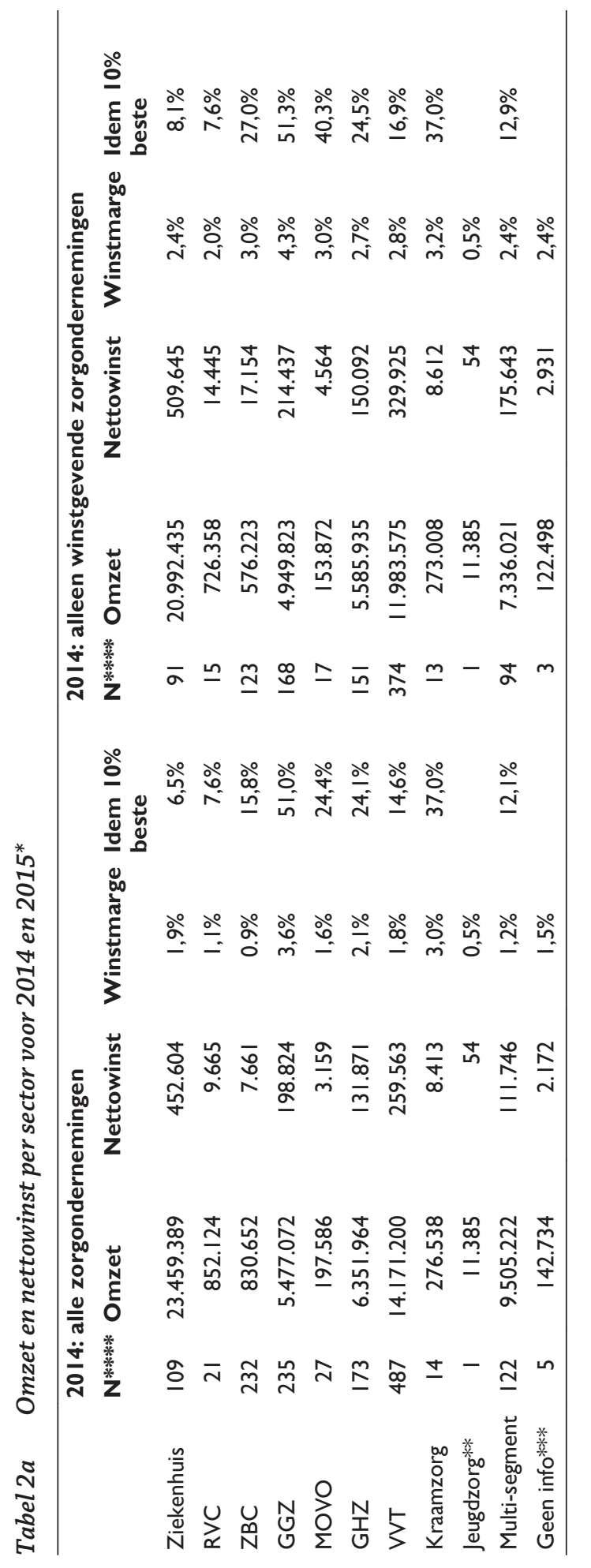




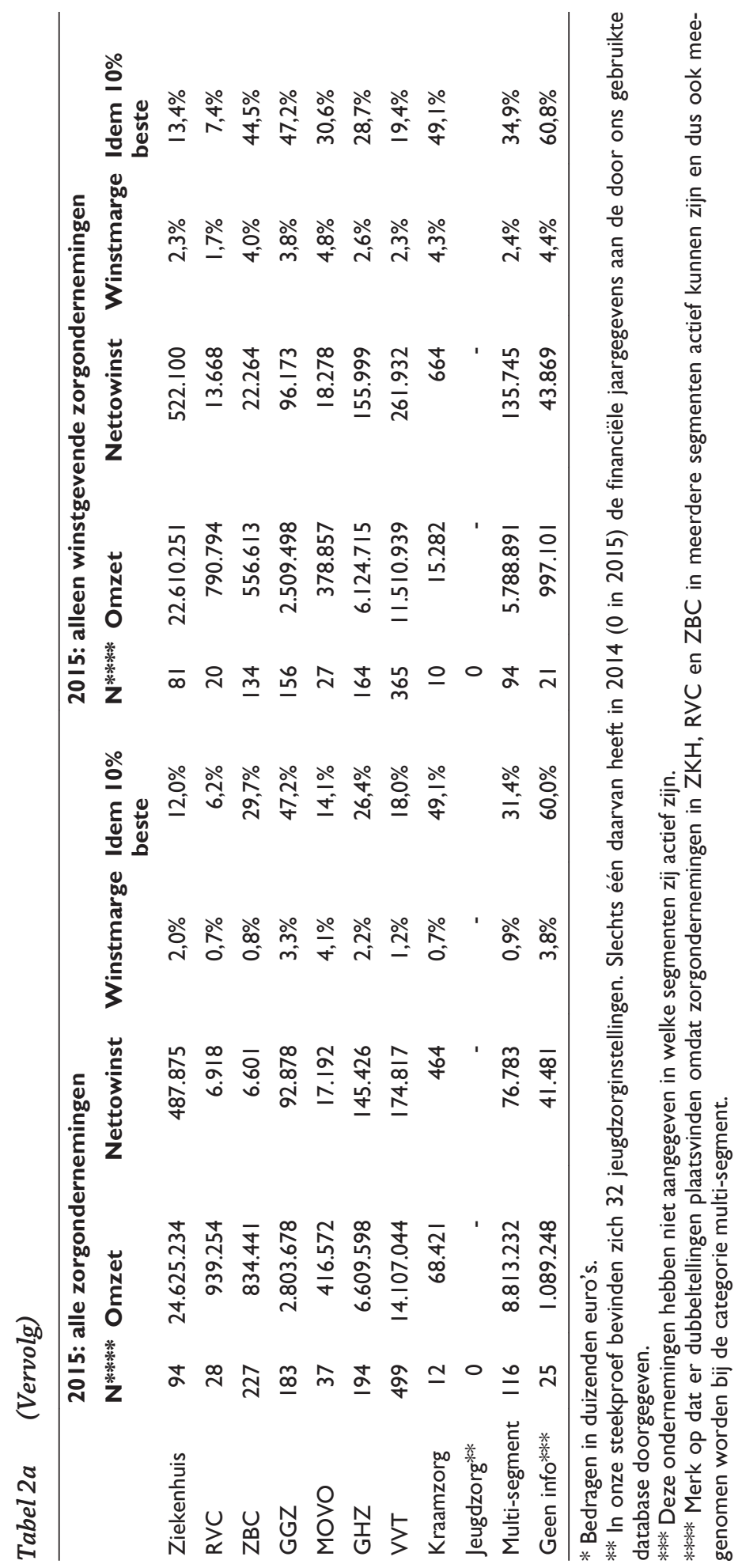




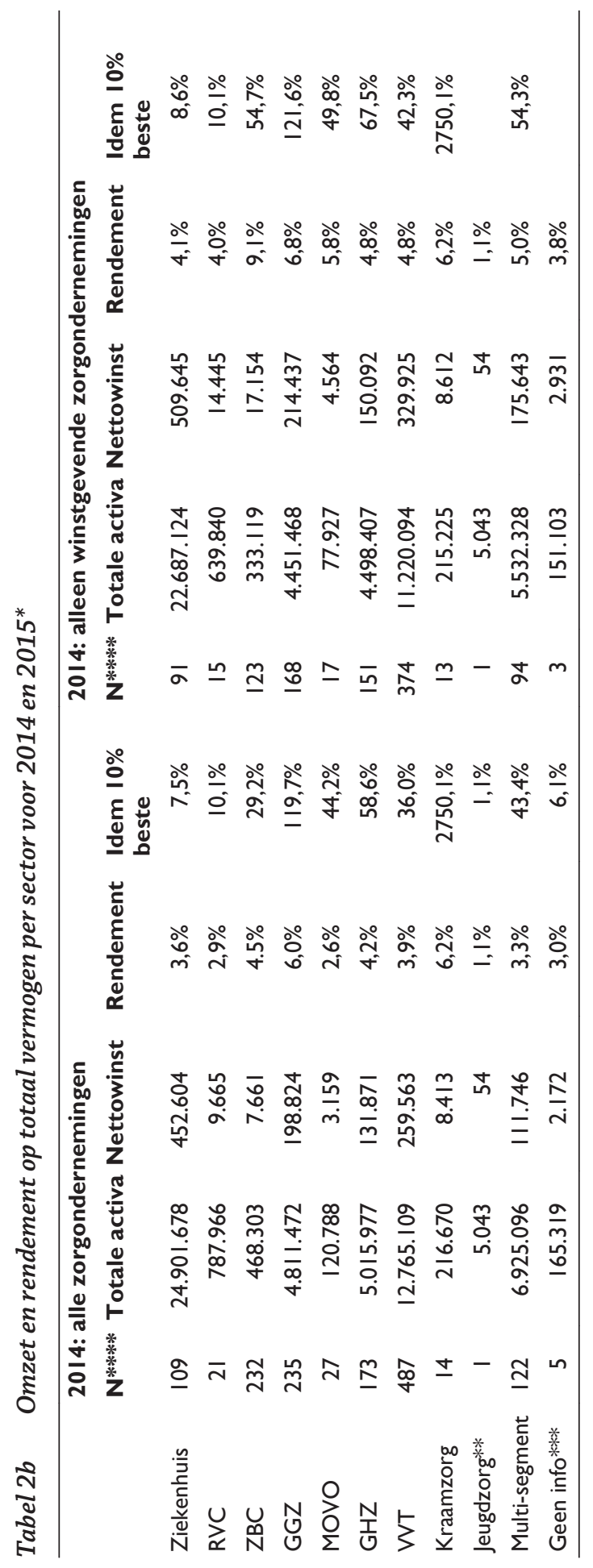




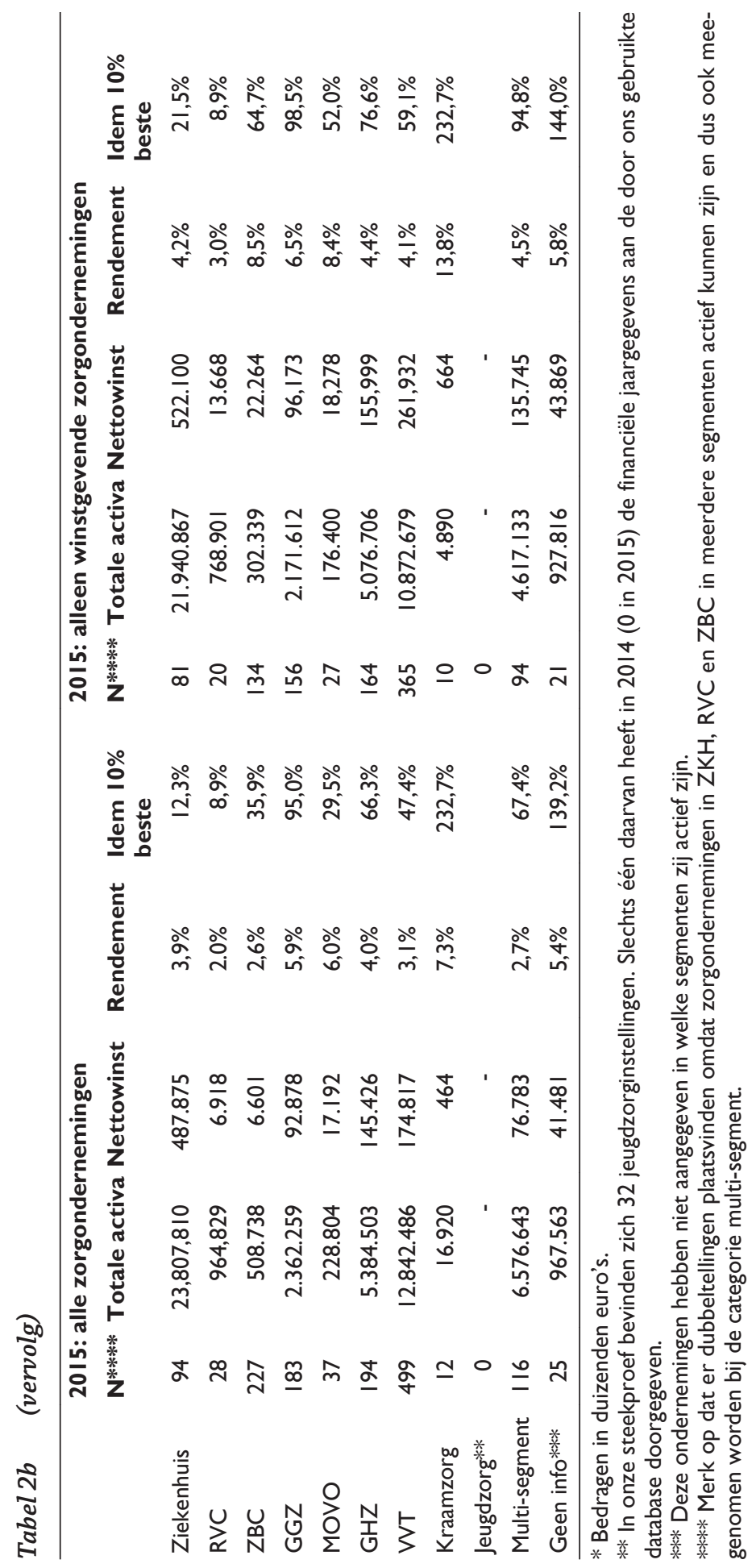


Als we alle instellingen meenemen, blijken zowel in 2014 als 2015 de nettowinstmarges van zorginstellingen gemiddeld rond de 2 procent te liggen, terwijl het rendement op het totale vermogen gemiddeld rond de 4 procent bedroeg. Het is moeilijk te bepalen wat een aanvaardbare winst is. Ziekenhuizen hebben een grote omvang aan fysiek kapitaal nodig (gebouwen, apparatuur, laboratoria en dergelijke), wat tot aanzienlijke periodieke vaste kosten kan leiden. Een winstmarge van bijna 2 procent lijkt dan niet onredelijk om een buffer te kunnen vormen voor onvoorspelbare risico's. Instellingen in de GGZ echter, die bijvoorbeeld ambulante begeleiding aanbieden, hebben voornamelijk personeel nodig en nauwelijks kapitaal. De periodieke vaste kosten zullen voor deze instellingen aanzienlijk lager liggen, zodat ook een lagere buffer nodig is. In dit geval lijkt de gemiddelde nettowinstmarge van 3,6 procent in 2014 (3,3 procent in 2015) die in de GGZ wordt behaald, relatief hoog in vergelijking met de ziekenhuizen.

Eenzelfde conclusie kunnen we trekken wanneer we naar het rendement op het totale vermogen kijken. Economisch gezien is het rendement op het totale vermogen een beloning voor het investeringsrisico dat de vermogensverschaffers nemen. Hoe hoger het risico om het geïnvesteerde vermogen te verliezen, hoe hoger het verwachte rendement zal zijn. Het ondernemingsrisico in de gezondheidszorg is naar onze mening beperkt, omdat de vraag naar gezondheidszorg grotendeels door de overheid gegarandeerd wordt. Het risico dat rest is dat de overheid bepaalt welke zorg wel gefinancierd wordt en welke niet. Zorginstellingen lopen dus het risico dat zorg die zij leveren (of delen hiervan) niet langer gefinancierd wordt door de overheid. Wanneer dit gebeurt, zullen zorginstellingen en/of hun investeerders op zoek gaan naar een alternatieve aanwending van het geïnvesteerd vermogen. Voor GGZ-instellingen die voornamelijk in onroerend goed geïnvesteerd hebben, zijn echter meer alternatieven beschikbaar dan voor ziekenhuizen die ook in medische apparatuur en dergelijke geïnvesteerd hebben. Ook hier lijkt het gemiddelde rendement op het totale vermogen van 6,0 procent in 2014 (5,9 procent in 2015) die in de GGZ wordt behaald, relatief hoog in vergelijking met de ziekenhuizen.

Zoals verwacht is het rendement op het totale vermogen hoger dan de nettowinstmarge en zijn de opbrengsten van alleen de winstgevende zorginstellingen hoger, terwijl de 10 procent meest winstgevende zorginstellingen daar dan weer ver boven uitsteken. Er blijkt een grote variatie in winstmarges binnen sectoren: de 10 procent best presterende zorgondernemingen binnen een sector behalen winstmarges (of behalen een rendement op het totale vermogen) die ver boven het gemiddelde liggen. Opvallend hierbij is dat vooral bij de GGZ-instellingen de 10 procent best presterende instellingen buitensporig hoge nettowinstmarges of rendementen op het totale vermogen kennen, respectievelijk meer dan 50 procent en bijna 100 procent.

Om een beter beeld te krijgen van de variatie van de financiële prestaties worden in tabel 3a voor de zorginstellingen die georganiseerd zijn als een bv, de zorg-bv's gepresenteerd met de hoogste nettowinstmarge respectievelijk het hoogste rendement op het totale vermogen voor zowel 2014 als 2015. In tabel 3b vinden we dezelfde data, maar nu voor de instellingen met de hoogste verliezen en laagste rendementen. 


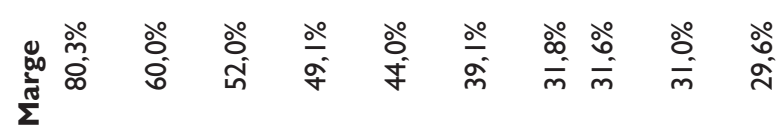

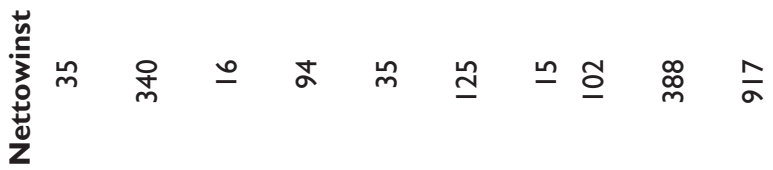

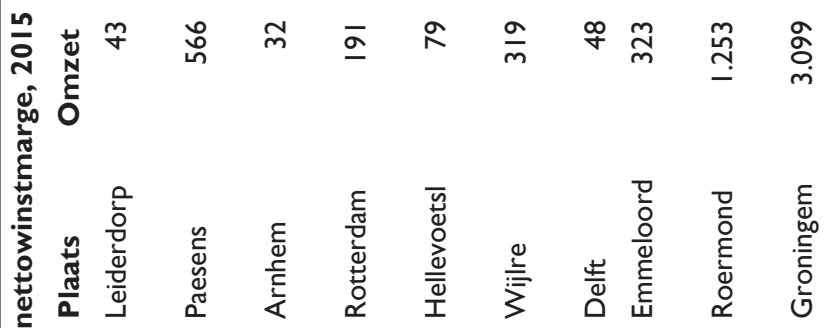

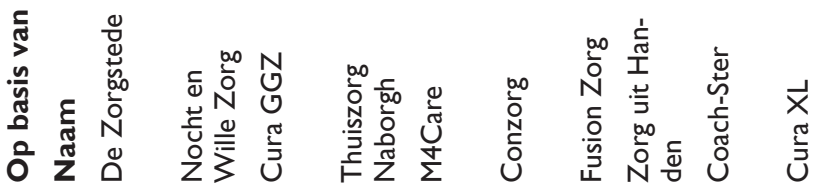

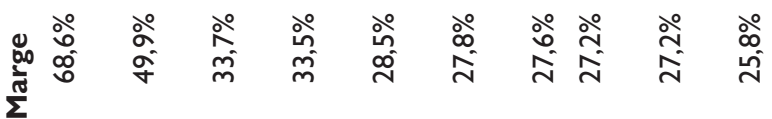
䓠

के อัด

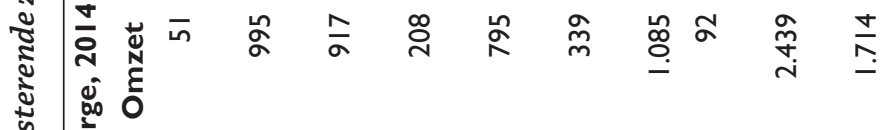

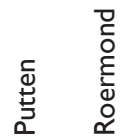

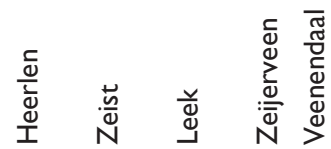

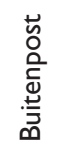




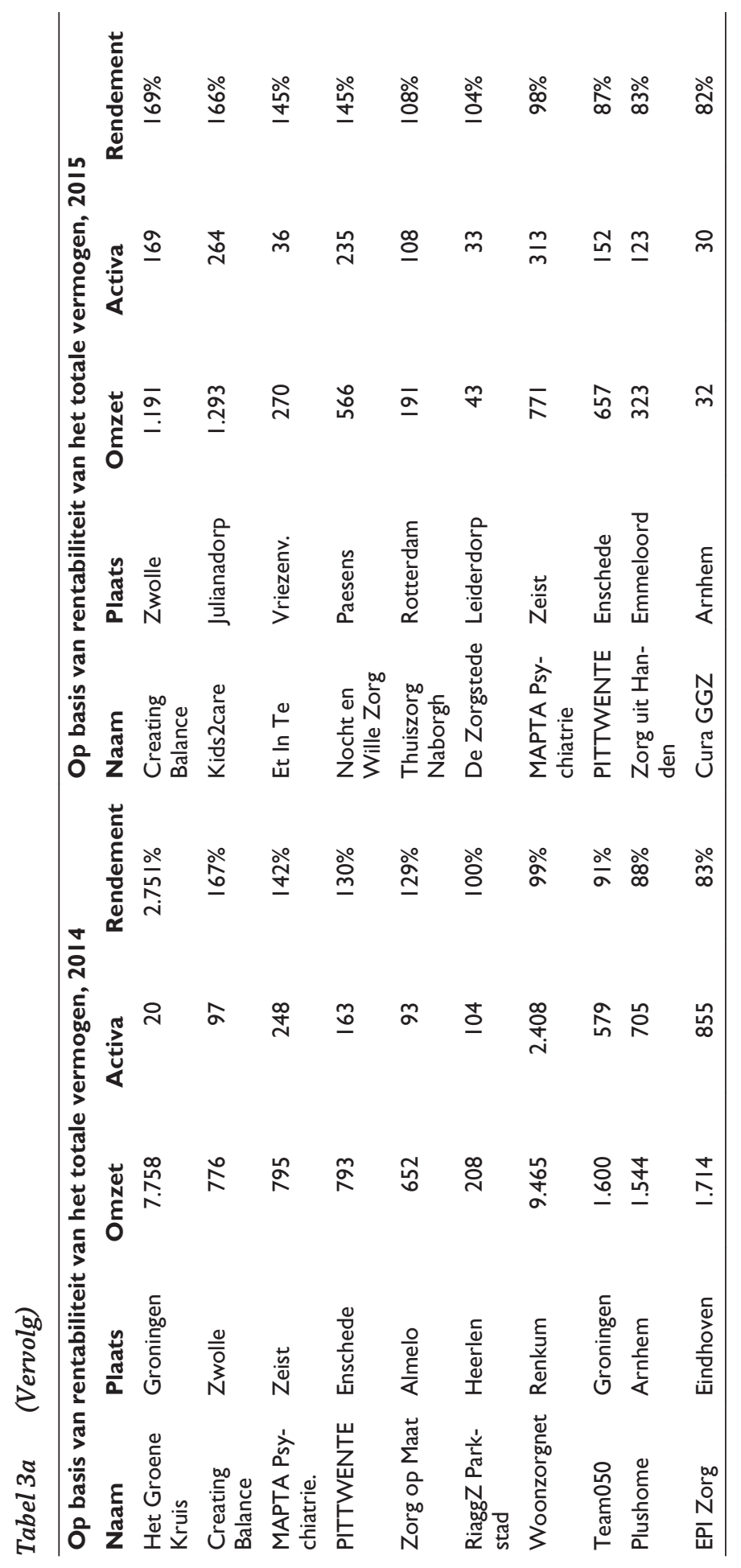




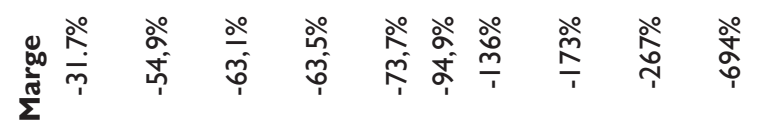

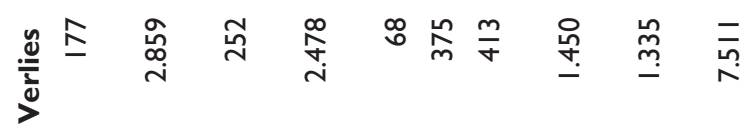

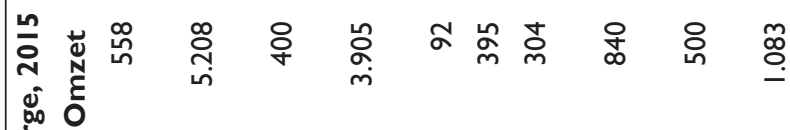

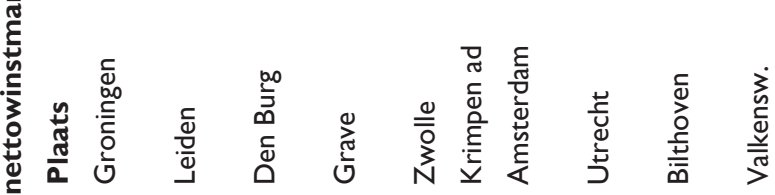

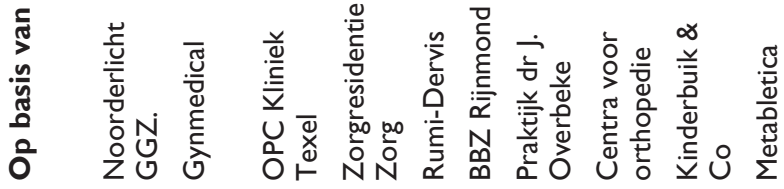

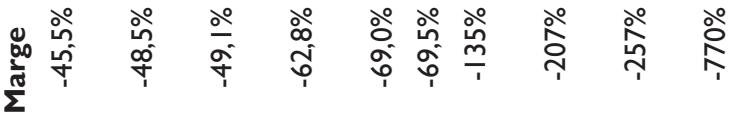

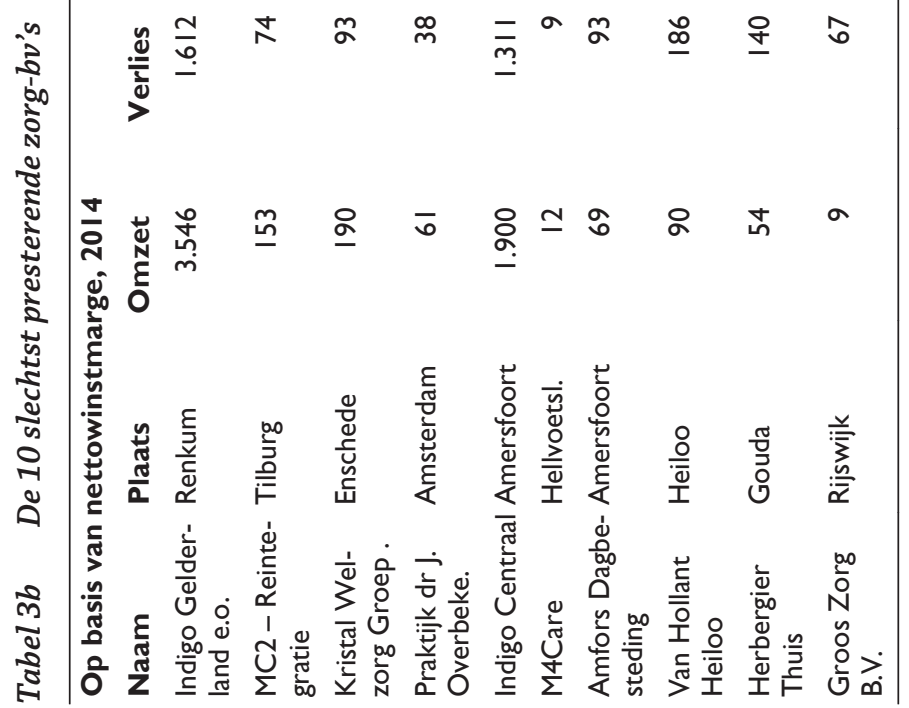




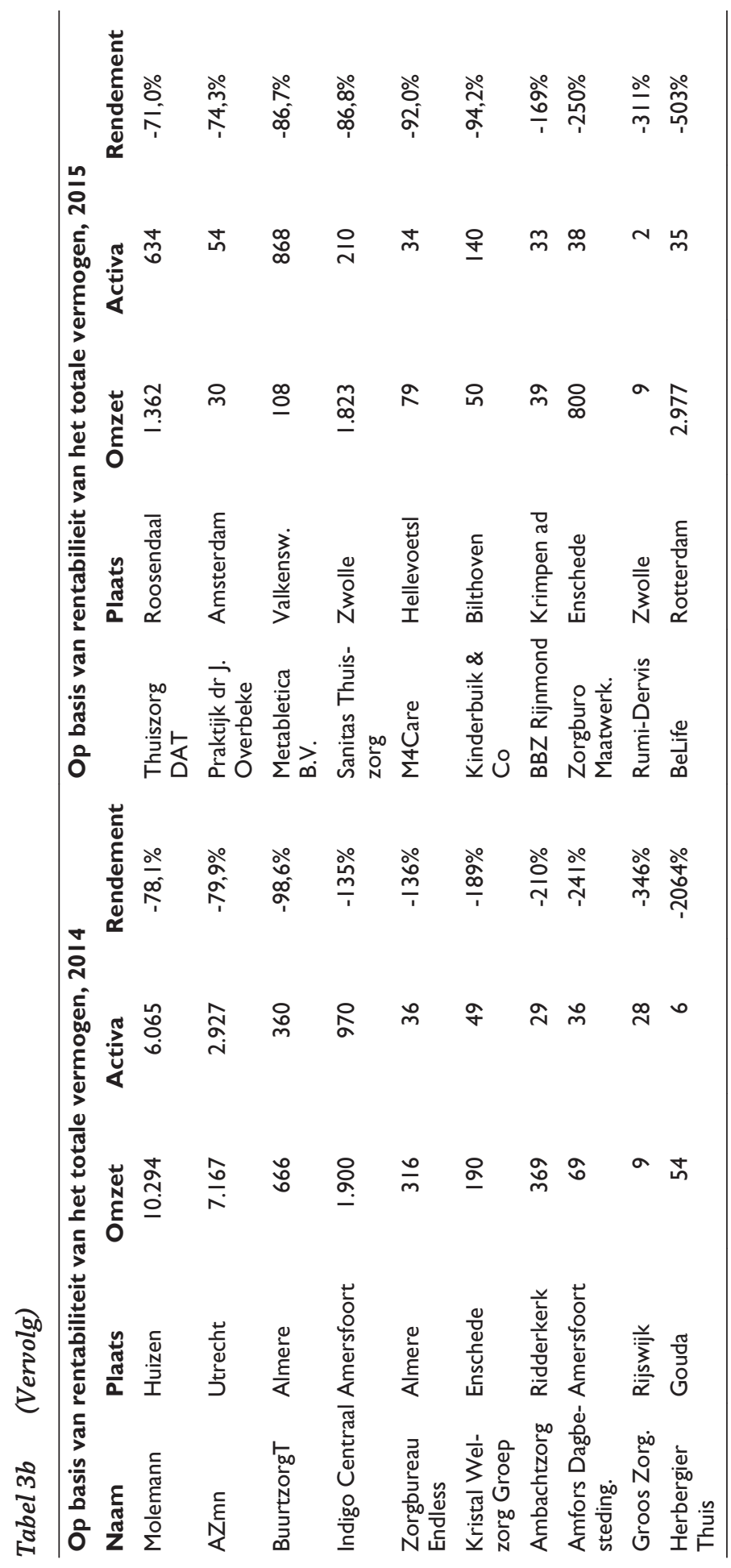


Wat opvalt is dat zowel de hoogste nettowinsten als de hoogste nettoverliezen extreem zijn. Dergelijke hoge of lage winstmarges zijn bij marktbedrijven uitzonderlijk. Alleen zeer succesvolle bedrijven als Apple of Microsoft komen in de buurt van die hoge winstmarges, maar de markten waarbinnen deze ondernemingen opereren lijken veel volatieler dan de markt voor gezondheidszorg. Zoals wij al betoogden, zouden de extreem hoge verliezen die we in tabel $3 b$ kunnen waarnemen in de marktsector slechts bij hoge uitzondering kunnen voorkomen. Deze bedrijven zouden snel van de markt verdwijnen wegens ernstig managementfalen. Van de vermelde bedrijven blijkt slechts een deel in 2015 zijn activiteiten gestaakt te hebben; de rest is nog steeds zelfstandig actief, ondanks de slechte financiële positie, of is opgegaan in een andere zorginstelling.

Een opvallend element in de tabellen $3 a$ en $3 b$ is dat zowel de omzetten van de meest winstgevende zorg-bv's als die van de meest verliesgevende zorg-bv's klein zijn, met een omzet die soms zeer laag is in vergelijking met de aanwezige activa. De gemiddelde omzet van alle zorginstellingen tezamen, inclusief ziekenhuizen, kan op basis van tabel 2 berekend worden als 42 miljoen euro per instelling, maar de gemiddelde omzet van de tien zorg-bv's met de hoogste nettowinsten is minder dan 1 miljoen euro. Voor de zorg-bv's met de hoogste verliezen (tabel 3b) geldt een analoge conclusie.

Dat de hoogste en de laagste winstmarges worden gerealiseerd door de kleinste zorginstellingen, blijkt ook nog eens uit de diagrammen in figuur 1 en figuur 2 . Voor het maken van deze diagrammen zijn de zorginstellingen in drie groepen ingedeeld, namelijk de kleinste, de middelgrote en de grootste instellingen. In iedere groep bevinden zich 456 zorgondernemingen.

Uit figuur 1 blijkt dat bij de kleinste zorgondernemingen gemiddeld de hoogste nettowinsten en -verliezen worden gemaakt. De meest winstgevende zorginstellingen in deze categorie hebben buitensporig hoge nettowinstmarges van gemiddeld 57,0 procent. Bij de allergrootste instellingen zijn de gemiddelde winsten lager (1,8 procent) en zijn de onderlinge verschillen tussen de best presterende en de slechtst presterende instellingen veel minder groot dan bij de kleinere instellingen. Uit figuur 2 blijkt dat deze conclusie niet verandert als we rendement op het vermogen als indicator voor de financiële prestaties van zorginstellingen gebruiken. 


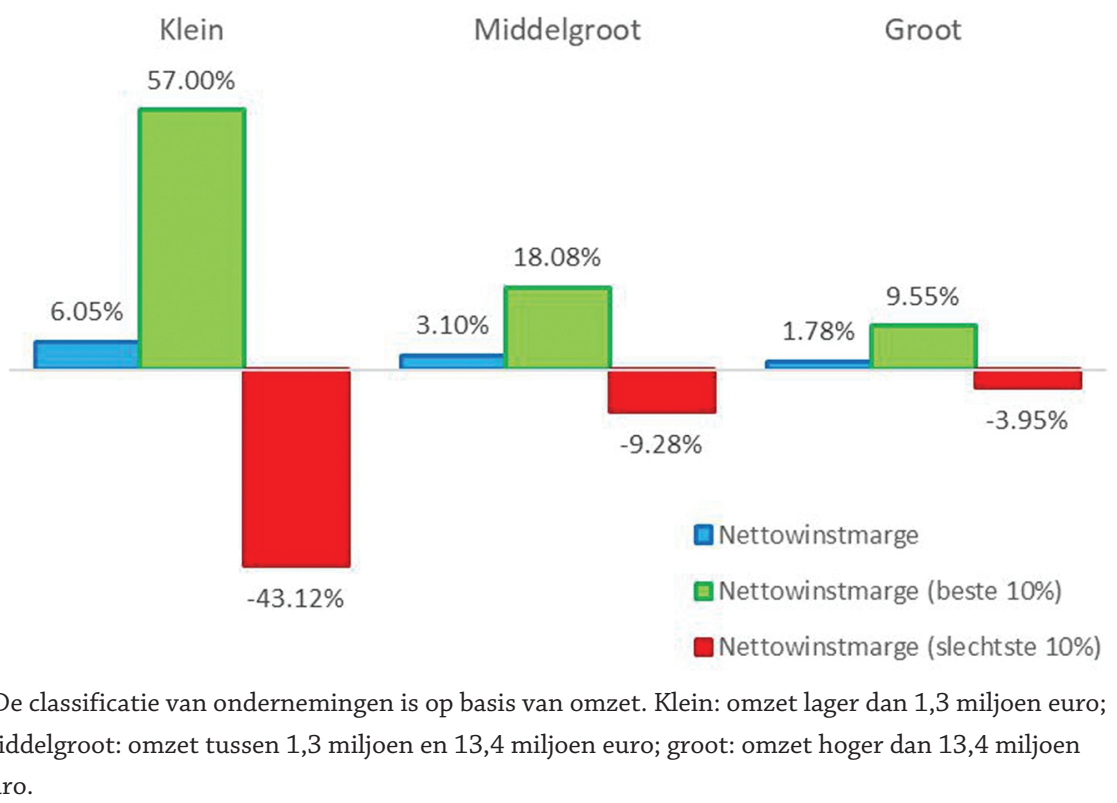

Figuur 1 Winstmarges en omvang zorginstellingen in 2015*

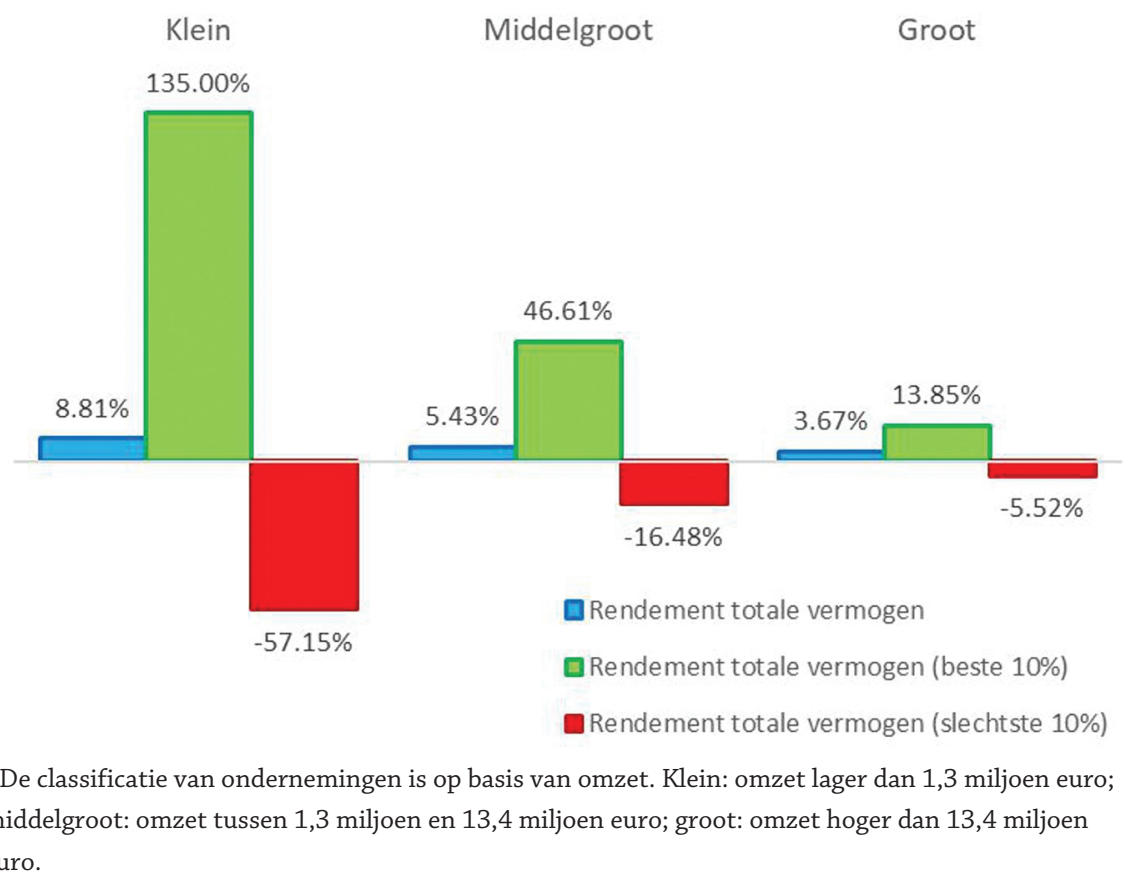

Figuur 2 Rendement op totaal vermogen en omvang zorginstellingen in 2015* 
Men zou echter verwachten dat juist de grote instellingen door hun omvang hun personeel flexibeler en efficiënter kunnen inzetten dan de kleinere instellingen en daardoor in staat zijn hogere winsten te boeken. Uit figuur 3 blijkt dat er van schaalvoordelen nauwelijks sprake is. Figuur 3 laat zien hoe de ratio omzet/totale activa varieert met de grootte van de onderneming. Bij schaalvoordelen zou deze ratio met de grootte van de onderneming moeten toenemen, maar dit blijkt in de zorgsector niet het geval te zijn. ${ }^{6}$ De ratio is voor de instellingen met de hoogste omzet ongeveer even hoog als voor de instellingen met de laagste omzet. Betrekkelijk kleine instellingen met een omzet tussen 1,5 en 4 miljoen euro lijken het meest efficiënt te zijn.

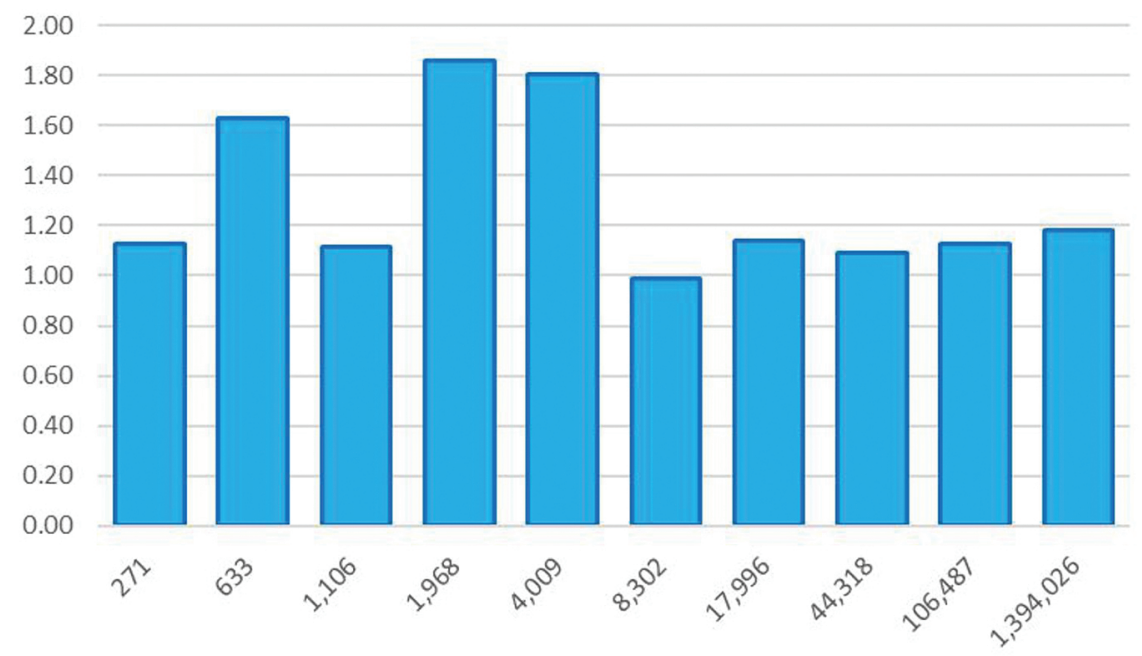

Figuur 3 Omloopsnelheid totale activa van zorgondernemingen in de sectoren GGZ, MOVO, GHZ, VVT, kraamzorg en jeugdzorg per omzetdeciel voor het jaar 2015

Het is zonder nader onderzoek van de administratie van de zorginstellingen niet na te gaan wat de oorzaak is van de (excessief) hoge winsten of hoge verliezen van kleine instellingen. De winsten zouden het gevolg kunnen zijn van te weinig geleverde zorg in verhouding tot het verkregen budget, om zodoende hogere winstuitkeringen voor de eigenaren, in het geval van zorg-bv's, te kunnen genereren. We kunnen deze suggestie nader bekijken door een vergelijking te maken met zorginstellingen die in een stichting zijn georganiseerd. Stichtingen mogen geen winst uitkeren aan de eigenaren en als er door stichtingen winsten gemaakt worden, lijkt hier het motief van 'zelfverrijking' derhalve afwezig. ${ }^{7}$ In tabel 4 zijn tien stichtingen met de hoogste winsten of hoogste verliezen respectievelijk de hoogste en de laagste rendementen opgenomen. Hierbij moet opgemerkt worden dat stichtingen ook inkomsten uit vrijwillige bijdragen van donors kunnen ontvangen. Deze giften worden in de door ons gebruikte database niet expliciet vermeld, zodat de data hiervoor niet gecorrigeerd kunnen worden. 
Uit tabel 4 blijkt ten eerste dat ook de stichtingen winsten maken, die zelfs hoger zijn dan de winsten bij de zorg-bv's, terwijl er ook buitensporig hoge verliezen worden geleden. Ten tweede blijkt dat, op een enkele uitzondering na, de (geringe) omvang van de instellingen bij de stichtingsvorm eveneens bepalend is voor de hoogte van de winsten of de verliezen. De gemiddelde omzet van zowel de zeer winstgevende als de zeer verlieslijdende stichtingen ligt ver beneden de landelijk gemiddelde omzet. ${ }^{8}$ 


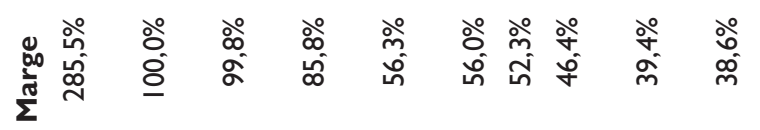

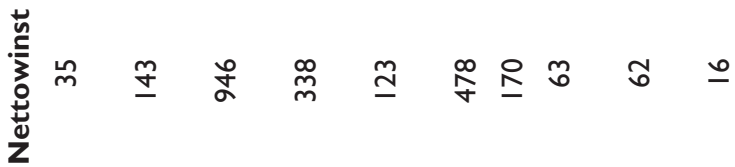

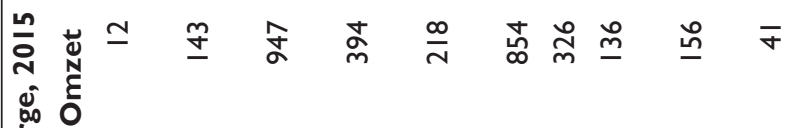

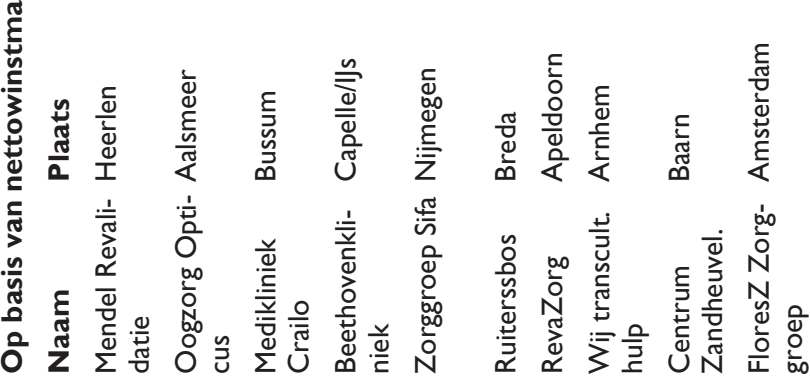

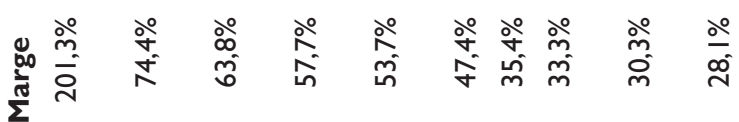

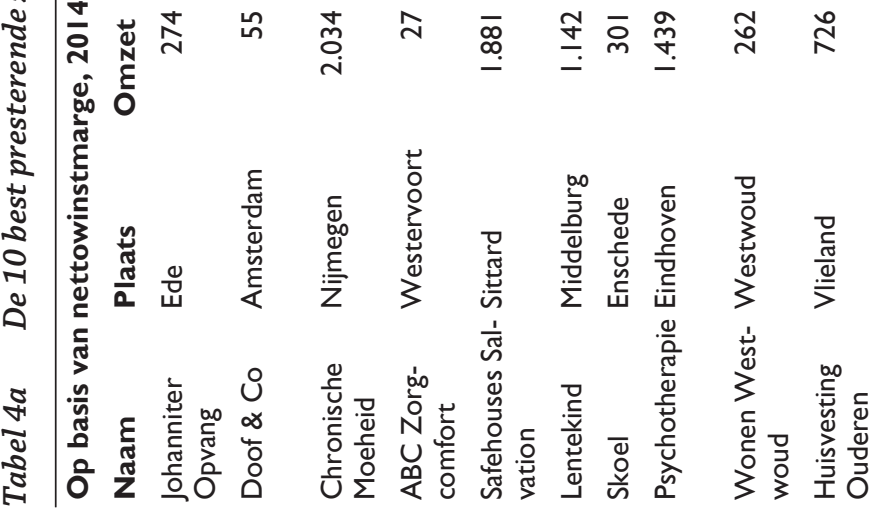




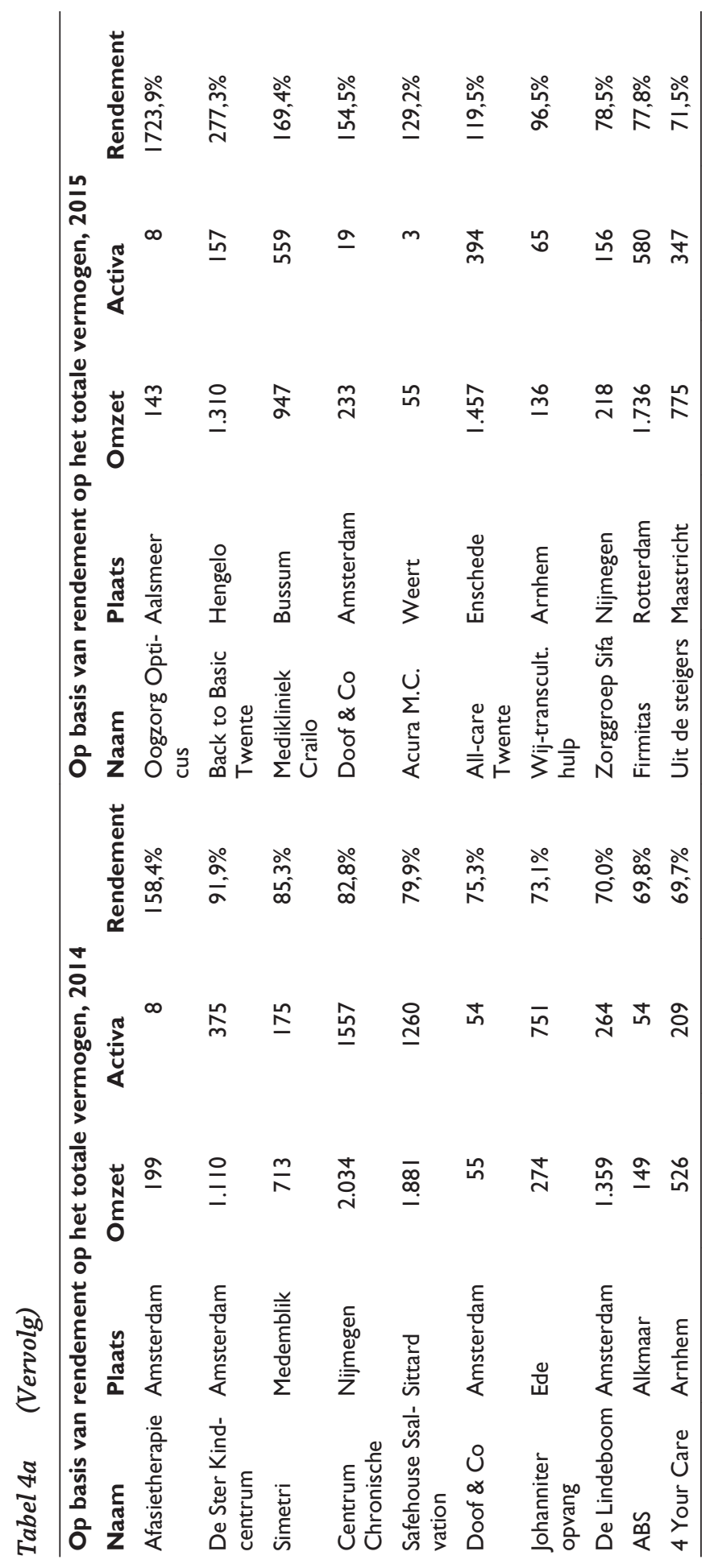


ฌ

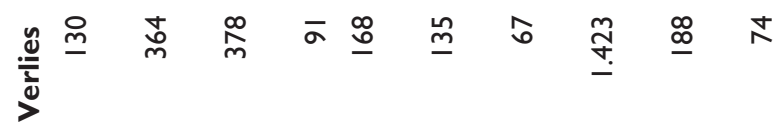

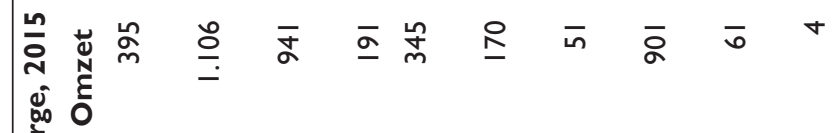
.

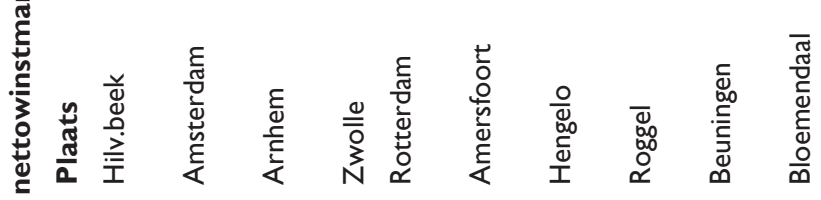

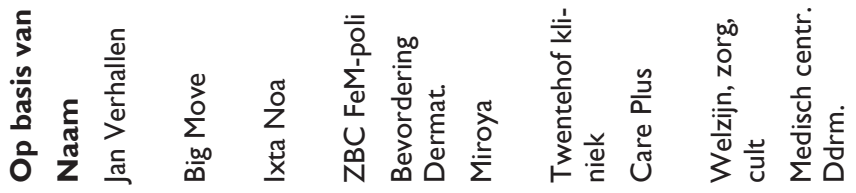

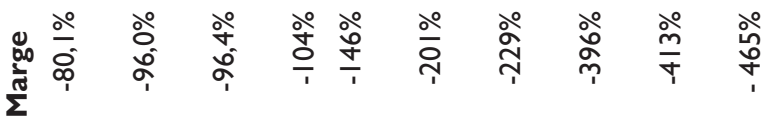

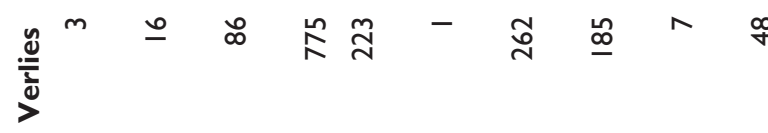

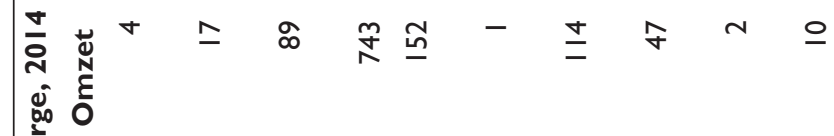

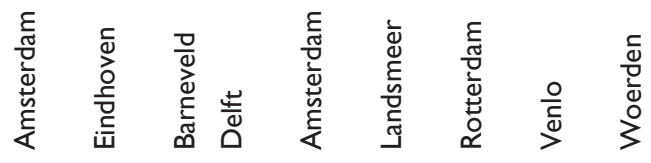

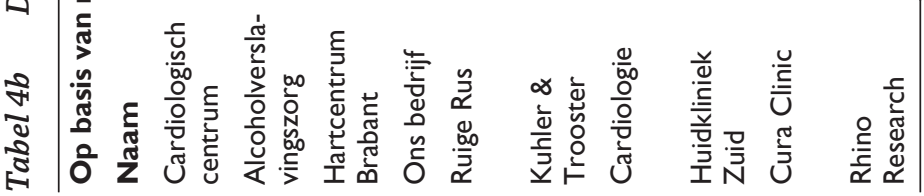




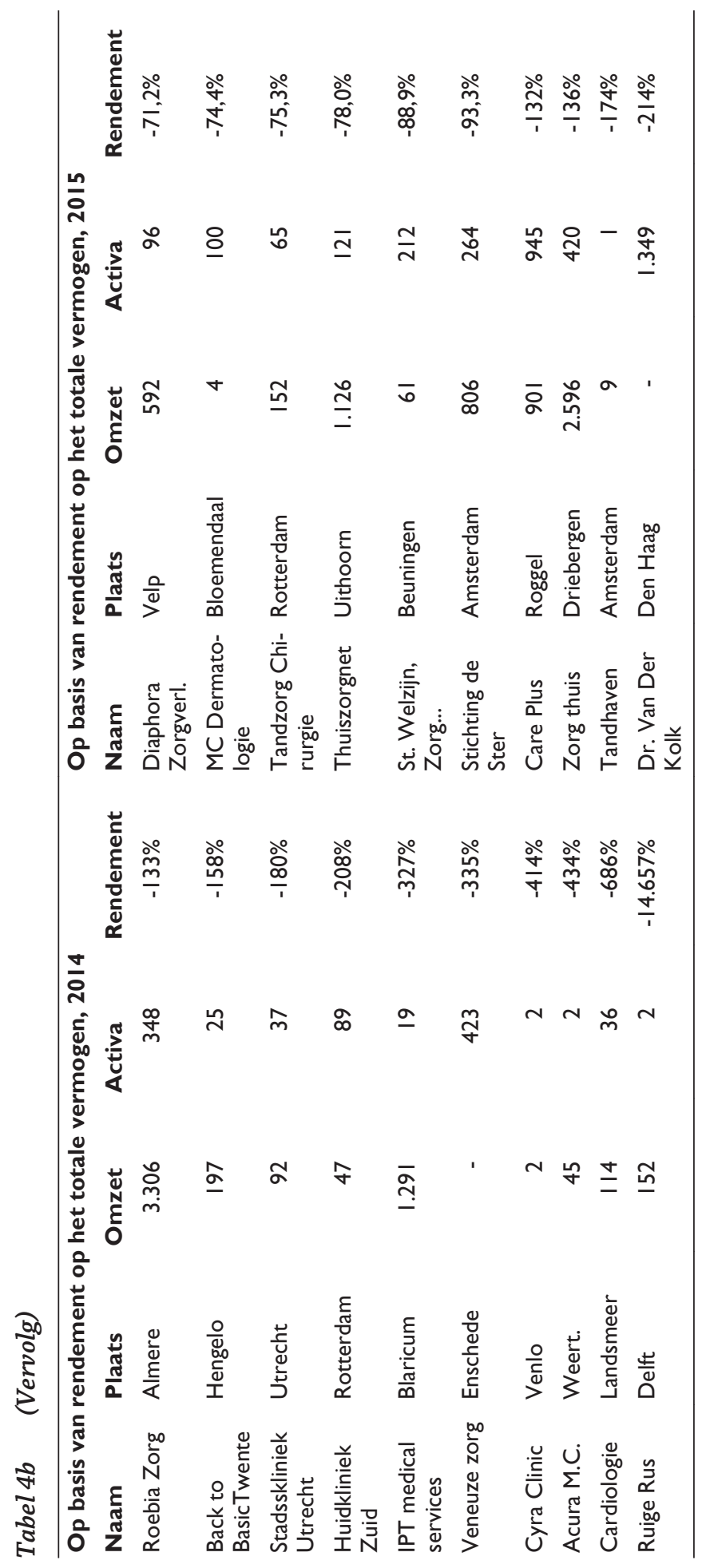




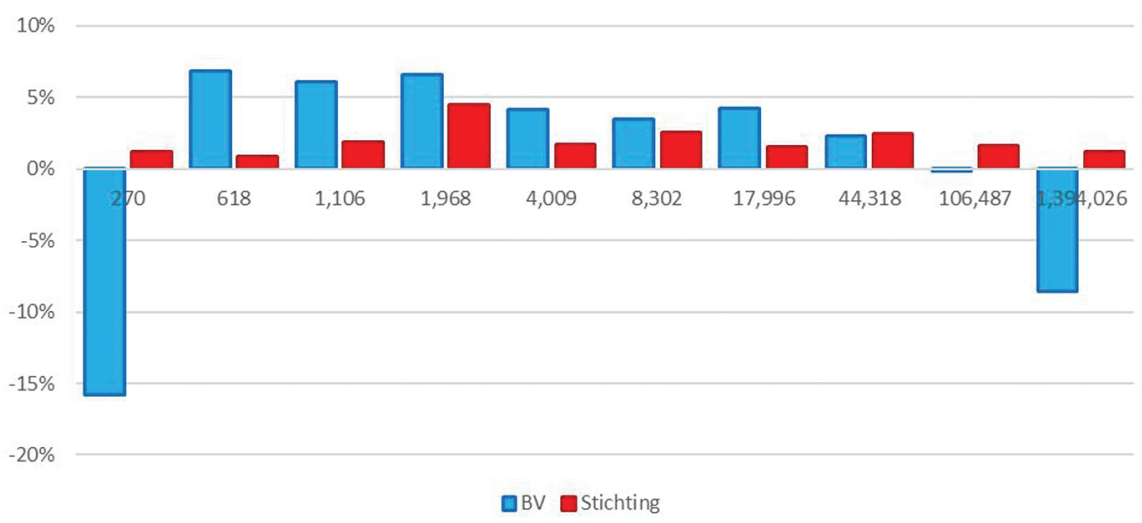

Figuur 4 Gemiddelde nettowinstmarge van stichtingen en bv's per omzetdeciel in 2015

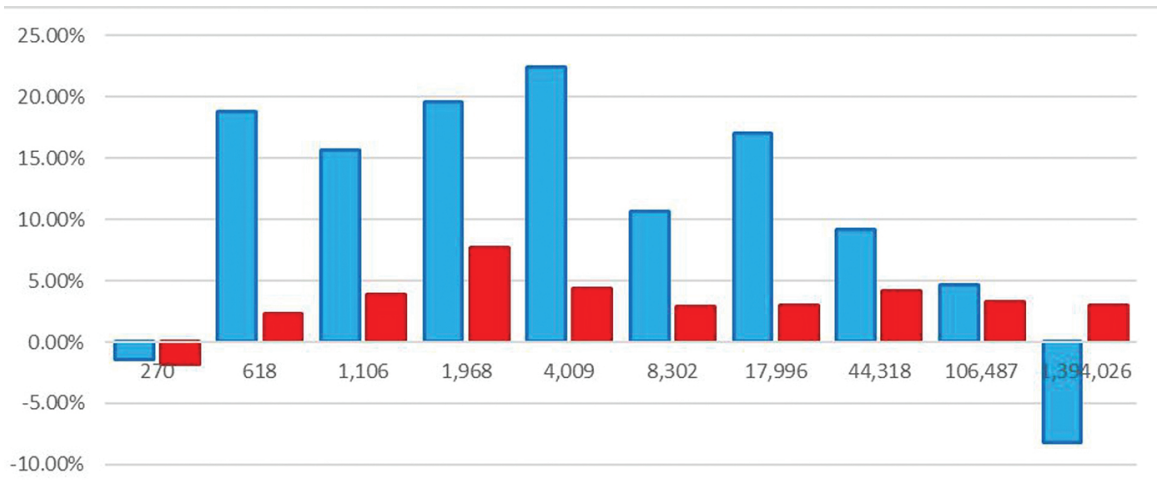

$\square B V \square$ Stichting

Figuur 5 Gemiddeld rendement op vermogen van stichtingen en bv's per omzetdeciel in 2015

Om een beter inzicht te krijgen in de relatie tussen winstgevendheid, bestuursvorm (stichting of bv) en omvang van de zorginstelling hebben we voor gegeven niveaus van de omzet het aantal stichtingen en bv's en de gemiddelde winsten bepaald. In de figuren 4 en 5 worden de resultaten daarvan weergegeven. Deze figuren zijn gebaseerd op de gegevens van 2015.

In de figuren zien we de gemiddelde prestaties van zorginstellingen per omzetdeciel. In figuur 4 wordt de nettowinstmarge als indicator gebruikt en in figuur 5 het rendement op het totale vermogen. Uit deze figuren blijkt dat voor de kleinste bv's met een omzet van gemiddeld 270.000 euro de verliesgevende instellingen het resultaat domineren voor beide indicatoren. Voor de kleinste stichtingen is de 


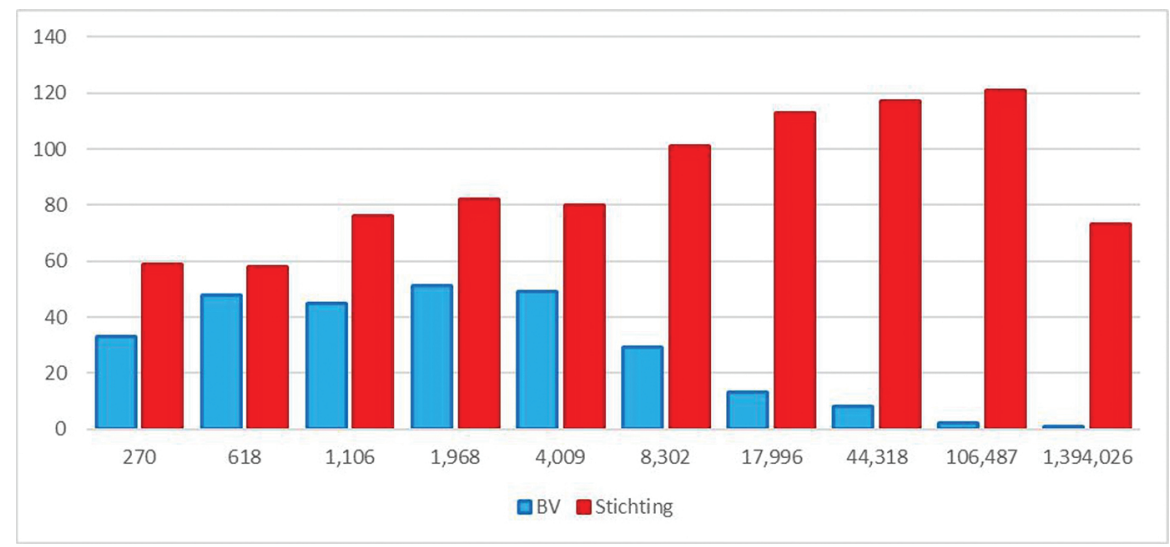

Figuur 6 Aantal zorgondernemingen per omzetdeciel in 2015

nettowinstmarge nog net positief, maar het rendement op het totale vermogen is negatief bij beide financiële indicatoren. In de decielen 2 tot en met 7 vinden we dat de bv's beter presteren dan de stichtingen op basis van beide indicatoren. Voor de grotere instellingen (decielen 8 en 9, omzet gemiddeld 44 miljoen euro of hoger) is het beeld minder eenduidig. Het rendement op het totale vermogen is net iets hoger bij de bv's; voor de gemiddelde nettowinstmarge geldt echter het omgekeerde. De allergrootste stichtingen (omzet hoger dan 1,3 miljard euro) kunnen betere financiële prestaties overleggen dan de grootste bv's. Zoals uit figuur 6 blijkt zijn er echter maar weinig zorg-bv's met zo'n hoge omzet; in het hoogste deciel is zelfs maar één bv werkzaam.

In figuur 6 wordt over de relatieve omvang van bv's en stichtingen meer informatie gegeven. Zoals men uit de figuur kan aflezen, heeft het overgrote deel van de bv's een omzet lager dan 8,3 miljoen euro, terwijl de meeste stichtingen juist een omzet groter dan 8,3 miljoen euro hebben. Stichtingen zijn dus gemiddeld groter dan bv's. Kennelijk is het voor ondernemers niet aantrekkelijk om een grote bv te runnen met meer dan 44 miljoen euro omzet. Een verklaring hiervoor zouden de publicatieverplichtingen voor Nederlandse private ondernemingen kunnen zijn. ${ }^{9}$ Ondernemingen met een omzet van 12 miljoen euro of minder kunnen als 'kleine onderneming' geclassificeerd worden, hetgeen betekent dat zij slechts een verkorte balans en beperkte toelichting in hun jaarrekening hoeven op te nemen en te deponeren bij de Kamer van Koophandel.

Vervolgens hebben we de zorginstellingen geordend naar omvang en ingedeeld in drie even grote groepen. In iedere groep hebben we de gemiddelde financiële prestaties van alle, van de 10 procent best presterende en van de 10 procent slechtst presterende bv's en stichtingen bepaald. In tabel 5 a staan de resultaten van deze exercitie weergegeven met de nettowinstmarge als indicator, en in tabel $5 \mathrm{~b}$ is het rendement op het totale vermogen als financiële indicator gebruikt. Deze tabellen bevestigen dat de best presterende kleine zorginstellingen met een omzet van 
minder dan 1,3 miljoen euro zowel in de bv-vorm als in de stichtingsvorm hoge winsten kunnen boeken, met winstmarges van gemiddeld meer dan 30 procent voor de instellingen met de hoogste winsten. Naarmate de instellingen groter worden, nemen de winstmarges af, maar bij de best presterende grote instellingen zijn die marges toch nog hoger dan 6 procent. Voor de verlieslijdende instellingen geldt iets soortgelijks. Deze verliezen zijn naar verhouding het grootst bij de kleinste instellingen en nemen af met de omvang van de instelling. Als we het rendement op het totale vermogen als indicator nemen, geldt een soortgelijk, hoewel iets minder eenduidig resultaat. De afwijkende resultaten voor de bvvorm lijken vooral gedreven doordat de middelgrote bv's een relatief laag geïnvesteerd vermogen hebben ten opzichte van de kleine en grote bv's. 


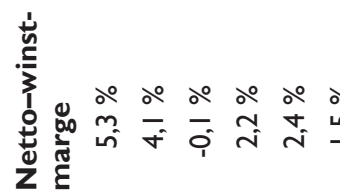

ํㅠㄹ

茜

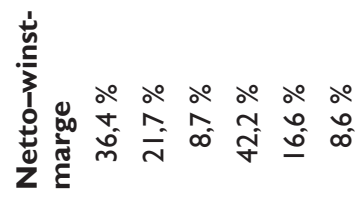

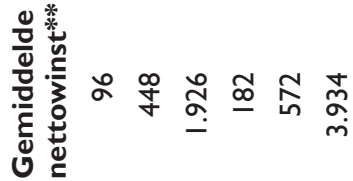

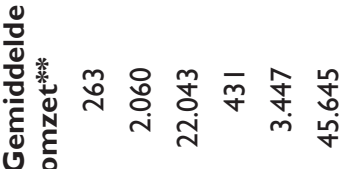

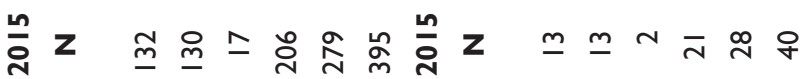

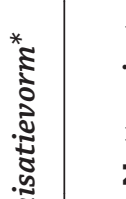

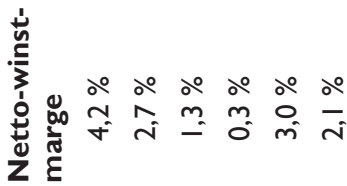

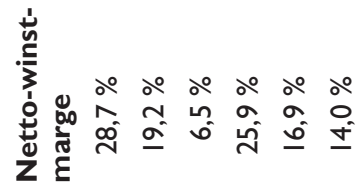

光

先

드 $\stackrel{m}{\wedge}$ 뜬 뚜

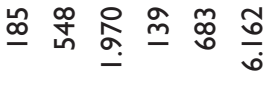

ํํㄹ

苞

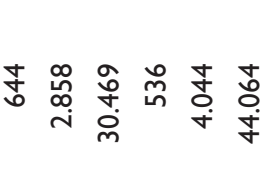

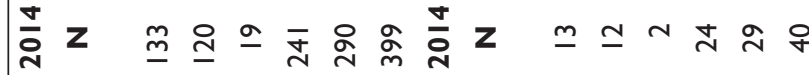

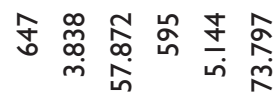

مَב
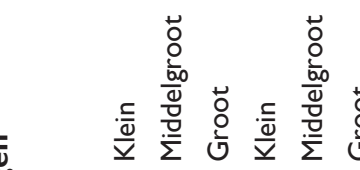

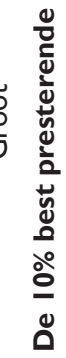

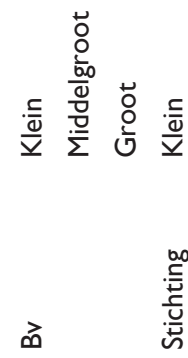

के

萜 


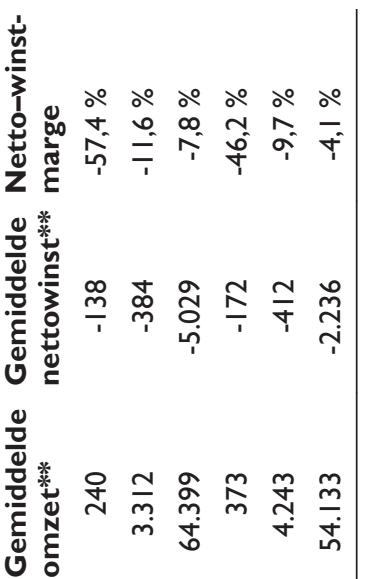

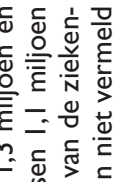

든

岁苞范

岂

ถิ $॥ \frac{5}{2}$

I

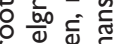

하뮤ำ

물

ํํำ

可高

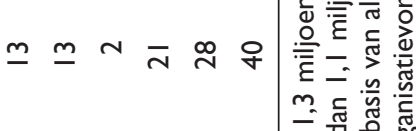

는 $z$

đั

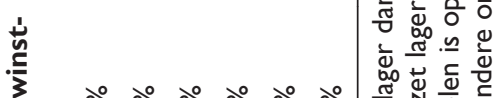

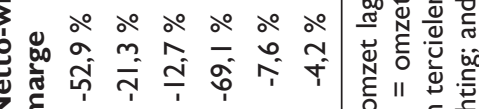

ब*

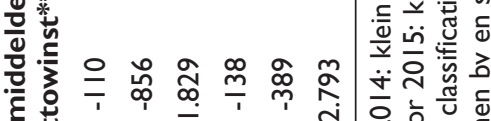

है

立定

$\frac{0}{0}$

뀬

咅

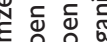

ॠ

产家

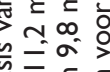

ํํㄹ

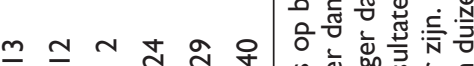

o

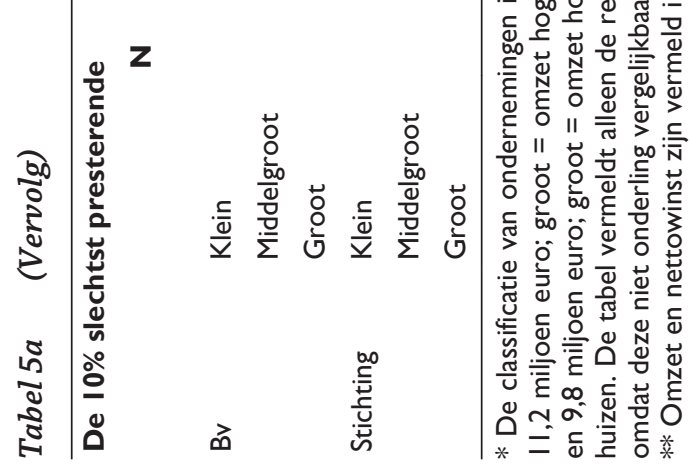




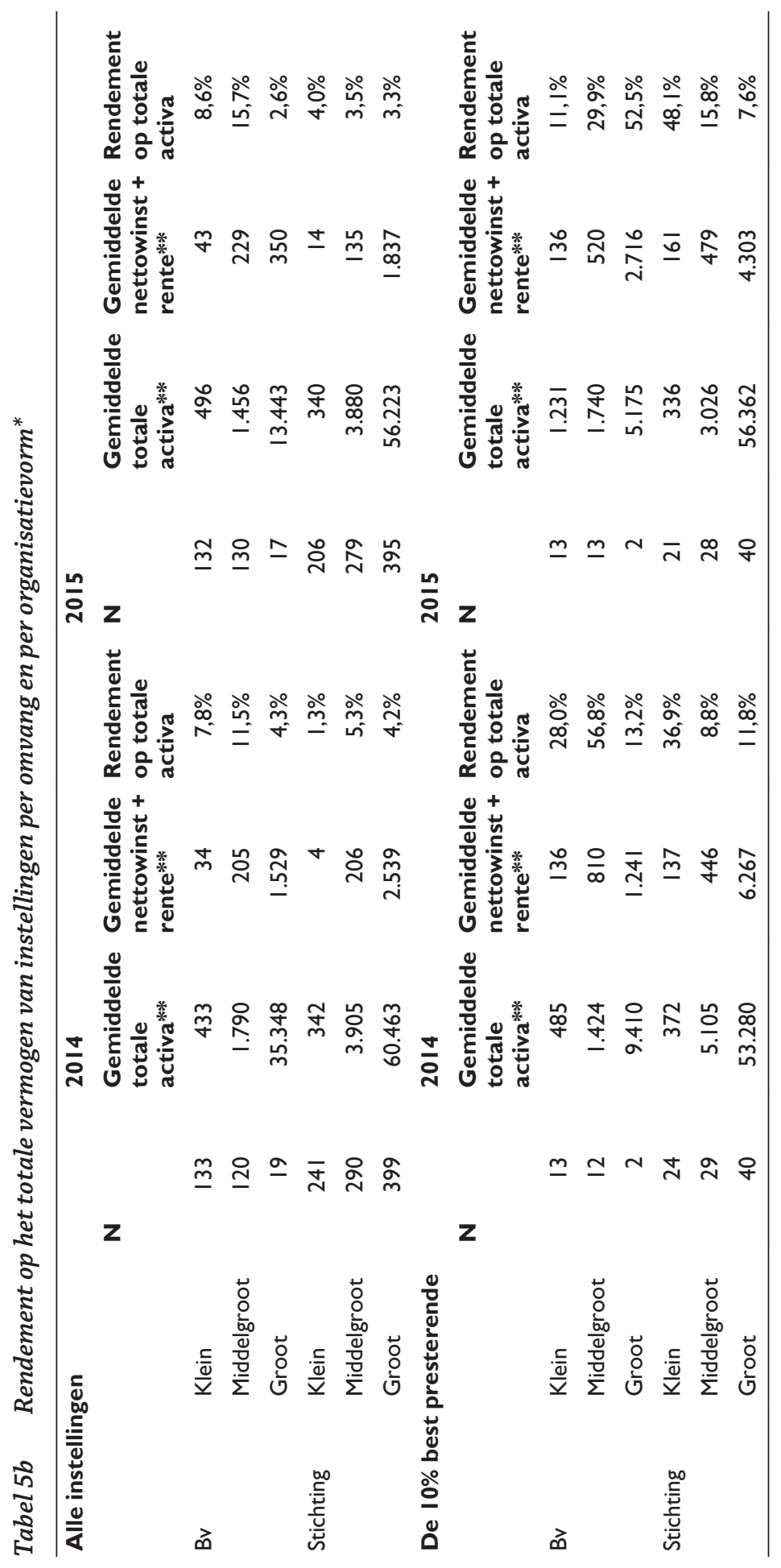




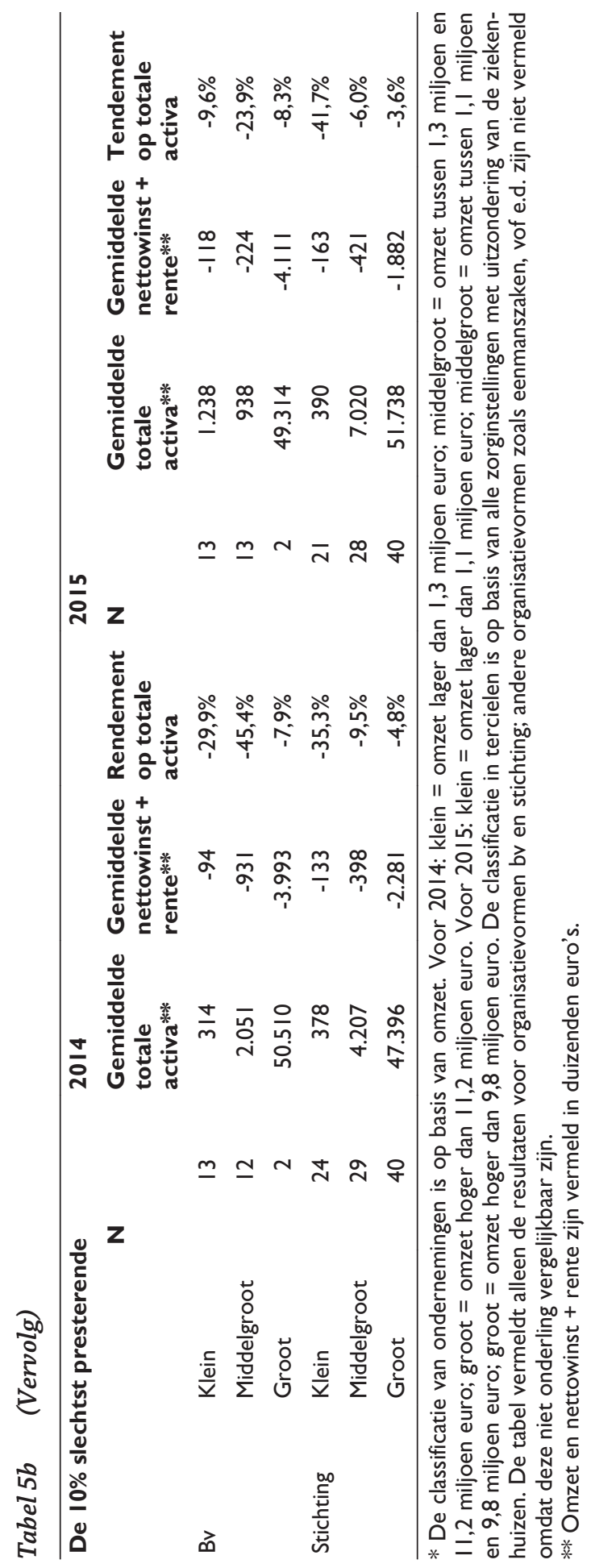


Op basis van deze gegevens kunnen we concluderen dat bij de kleinere zorginstellingen (zowel bv's als stichtingen) de variantie van de financiële prestaties onevenredig groot is. De oorzaken van deze hoge variantie zijn met onze gegevens moeilijk te achterhalen. Het lijkt erop dat kleinere instellingen meer dan grotere er op uit zijn spectaculaire financiële resultaten te halen. Dat lukt ook bij een aantal zorginstellingen, waar winstmarges variërend tussen 25,9 procent en 42,2 procent worden gehaald (zie tabel $5 \mathrm{a}$ ). Het toont eens te meer aan dat het kennelijk mogelijk is met weinig financiële middelen een 'gokje te wagen' op de zorgmarkt.

\section{Conclusies en beleidsimplicaties}

Een eerste algemene conclusie die te trekken is op basis van de cijfers op de website jaarverslagenzorg.nl, is dat de gemiddelde nettowinst van de zorginstellingen met ongeveer 2 procent over 2014 en 2015 in vergelijking met de marktsector niet uitzonderlijk laag is (zie De Nederlandsche Bank, 2006). Alleen de nettowinst van de GGZ-instellingen met 3,6 procent in 2014 en 3,3 procent in 2015 lijkt daar duidelijk boven uit te steken. Eerder onderzoek naar het gedrag van GGZ-aanbieders (Douven, Remmerswaal \& Zoutenbier, 2016) heeft laten zien dat 75 procent van de aanbieders in deze sector reageert op financiële prikkels. Zij reageren strategisch op tariefgrenzen en behandelen daardoor langer dan aanbieders die zich niet door de tariefstructuur laten leiden. Aangezien het in deze sector lastig is aan te tonen welke behandeling effectief is, bestaat daar ook de ruimte voor tegenover de opdrachtgevers (ziektekostenverzekeraars en/of gemeenten). Dit zou kunnen verklaren waarom de winsten in deze sector hoger zijn dan in andere sectoren.

Onze bevindingen ten aanzien van de GGZ-sector lijken in tegenspraak met het rapport over de 'barometer van de Nederlandse gezondheidszorg' van EY (2016). EY schrijft: 'Het sector rendement zal voor het eerst sinds lange tijd rond of onder de kritische norm van 1,5\% uitkomen.' EY vermeldt overigens niet welke databronnen zijn gebruikt bij het onderzoek naar de financiële prestaties van de zorgsector.

Bij verliesgevende aanbieders zijn specifieke factoren in het geding. Zo zijn verliesgevende aanbieders (stichtingen of bv's) veelal gelieerd aan bv's die wel financieel gezond zijn. ${ }^{10}$ Bovendien blijkt vooral bij de bv's het personeelsbestand structureel te hoog te zijn in verhouding tot de omzet. Dit duidt wellicht op een niet rationeel ingevuld productieproces dan wel dat op kosten van de eigen bv of stichting werkzaamheden voor de gelieerde bv worden verricht. Dit zou een nader onderzoek vergen. Op grond van deze specifieke factoren concluderen wij dat het zonder meer berekenen van een gemiddelde nettowinstmarge over alle zorginstellingen, zoals EY doet, tot een vertekening van het resultaat kan leiden. Het is minstens een nuttige check het effect van instellingen met excessieve financiële resultaten op de gemiddelde winsten van de zorginstellingen in beschouwing te nemen. 
Een tweede bevinding is dat de kleinste zorginstellingen, waarover de financiële gegevens bekend zijn, in staat zijn exorbitant hoge nettowinsten te maken van soms meer dan 40 procent op de omzet. Voor grotere instellingen (zowel stichtingen als bv's) zijn de gemiddelde winstmarges lager, terwijl voor de zorgsector in zijn geheel de nettowinstmarge rond de 2 procent ligt. Zoals we al eerder hebben opgemerkt, staan de data die wij gebruikt hebben het niet toe een algemene verklaring te geven voor extreem hoge winsten, noch voor de extreem hoge verliezen, die we ook geconstateerd hebben bij de kleinste instellingen.

Voor een aantal kleine winstgevende zorg-bv's hebben wij naar de meer gedetailleerde jaarrekeningen gekeken. Bij sommige van deze bv's konden wij door een vergelijking te maken van het gedeclareerde aantal uren met het aantal uren dat inzetbaar was op grond van het aanwezige personeel, constateren dat er te veel uren waren gedeclareerd. Dergelijke 'rekensommen' kunnen echter alleen gemaakt worden als het aantal gedeclareerde zorguren gerapporteerd wordt. Dit is echter maar voor een klein aantal zorgondernemingen het geval.

Een verklaring voor de hoge winsten zou derhalve kunnen zijn dat kleine zorginstellingen te veel uren declareren om zo tot hogere winsten te kunnen komen, die naar de eigenaren van de bv's vloeien. Inderdaad hebben wij bij sommige kleine zorg-bv's hoge dividenduitkeringen aangetroffen. Bij deze zorg-bv's bestond de directie uit de aandeelhouders van de bv's en deze dubbelrol 'nodigde' kennelijk uit tot onjuiste declaraties. Anderzijds laat dat de vraag onbeantwoord waarom ook kleine zorginstellingen die georganiseerd zijn als stichtingen hoge winstmarges kunnen realiseren. Stichtingen mogen geen winsten uitkeren en de neiging tot het kunstmatig opvoeren van de winst zal dan naar verwachting geringer zijn. Bij de stichtingen kunnen we echter ook buitengewone financiële transacties waarnemen die bij een normale bedrijfsvoering in de marktsector niet gauw zouden voorkomen. Bovendien worden er ook door kleine zorginstellingen die als een stichting zijn georganiseerd grote verliezen geleden.

Een andere verklaring voor de hoge winsten zou gelegen kunnen zijn in een hoog ondernemersrisico. De gereguleerde vraag in de zorgmarkt suggereert dat het risico met betrekking tot de omzet relatief laag zal zijn. Aangezien echter onder de kleine instellingen zowel extreem hoge winsten als extreem hoge verliezen worden geleden, zou een alternatieve verklaring kunnen zijn dat de zorgmarkt door de aantrekkelijke winsten die er gerealiseerd kunnen worden, ondernemers met weinig ervaring in de zorg aantrekt die uit zijn op hoge winsten. Een groot aantal van hen is echter niet in staat de gehoopte winsten te realiseren. Aanvullend onderzoek is hier echter nodig om het gedrag van de 'kleine' zorgondernemers te verklaren.

Een derde conclusie op basis van onze cijfers is dat commerciële bv's een veel lagere omzet hebben dan niet-commerciële stichtingen. De meeste bv's hebben een omzet van rond de 1 miljoen euro; er zijn vrijwel geen bv's met een omzet hoger dan 18 miljoen euro. Zoals wij eerder suggereerden, zou een verklaring hiervoor kunnen zijn dat de publicatieverplichtingen voor Nederlandse private ondernemingen minder stringent zijn voor ondernemingen met een omzet van 12 miljoen euro of minder. 'Kleine ondernemingen' in de zorg blijven daardoor grotendeels onder de radar van toezichthouders of accountants. 
Of de relatief hoge winsten te verklaren zijn door fraude bij declaraties of doordat zorginstellingen in staat zijn zeer efficiënt te werken, in beide gevallen lijkt de conclusie gerechtvaardigd dat de (impliciete) tarieven die door de overheid zijn vastgelegd voor de declarabele zorguren, dan wel voor de behandeling bij zorg in natura, de ruimte voor de hier gesignaleerde hoge winsten bieden. De hoogte van deze tarieven dient derhalve heroverwogen te worden. Gegeven de decentralisatie naar gemeenten van een groot deel van de zorg ligt hier een taak voor de gemeenten.

De staatssecretaris voor Volksgezondheid, Welzijn en Sport, Martin van Rijn, heeft in antwoord op Kamervragen gesteld dat zorgbedrijven winsten nodig hebben om hun continuïteit te waarborgen. Bedrijven zijn daarbij vrij hoe ze hun winsten aanwenden. Bij het uitkeren van dividenden dient echter volgens de staatssecretaris wel bekeken te worden of er geen sprake is van woekerwinsten, want daarvoor 'moet in de zorg geen plaats zijn' (www.rijksoverheid.nl, 2016, 2). Hij definieerde daarbij niet wanneer er sprake is van woekerwinsten. De casus waarover hem vragen werden gesteld, betrof het zorgbedrijf Boriz B.V. uit Velp, met een omzet van 1 miljoen euro, dat slechts de helft van zijn omzet aan zorg besteedde, maar wel dividenden uitkeerde aan directeuren/aandeelhouders van in totaal bijna 400.000 euro. Zonder een maximum te stellen aan de te behalen winsten, alsmede aan de dividenden die uit deze winsten mogen worden gefinancierd, kunnen zorgbedrijven ongehinderd winsten inzetten voor 'oneigenlijke bevoordeling of belangenverstrengeling' (t.a.p.; www.rijksoverheid.nl, 2016, 2).

Gegeven de door ons geconstateerde winsten, vooral bij de kleinere zorgbedrijven, is een evidente implicatie van ons onderzoek voor het beleid dat de overheid een maximum zou moeten stellen aan de te behalen winsten, alsmede aan de dividenden die uit deze winsten worden gefinancierd. Het stellen van een maximumwinst is echter niet effectief; hoge winsten zijn eenvoudig weg te sluizen via managementfees, advieskosten, kosten van leningen, buitengewone lasten en dergelijke, waardoor de gerapporteerde winst onder het gestelde maximum blijft. Het lijkt derhalve noodzakelijk eisen te stellen aan de daadwerkelijk te leveren zorg in verhouding tot de omzet.

Los van de regulering van winsten van zorginstellingen heeft ons onderzoek de noodzaak laten zien van meer transparantie en meer toezicht op de financiële prestaties van zorginstellingen. De financiële gegevens die door zorginstellingen op DigiMV worden gedeponeerd, blijken vaak niet te kloppen of niet volledig te zijn. Daarnaast levert een groot aantal kleine zorgbedrijven hun financiële gegevens niet eens aan. Zoals we uit tabel 1 kunnen aflezen, gaat het om ongeveer 40 procent van het totaal aantal zorginstellingen waarvan de financiële resultaten niet bekend zijn. Over de resultaten en activiteiten van deze bedrijven kunnen wij derhalve slechts gissen. Gezien onze bevindingen is de kans groot dat deze (vaak zeer kleine) zorgbedrijven excessief hoge winsten dan wel excessief hoge verliezen hebben geboekt. Het is vanuit het oogpunt van de verantwoording naar de belastingbetaler onwenselijk dat een deel van de besteding van het publieke zorggeld buiten iedere waarneming van financieel toezicht valt. Wij zouden er dan ook voor willen pleiten dat alle bedrijven die zich bezighouden met de besteding van zorggeld, een financiële verantwoordingsplicht krijgen. Daarbij zouden ze niet 
alleen hun gegevens bij de publieke site jaarverslagenzorg.nl beschikbaar moeten stellen, maar ook zou er een volledig door een accountant goedgekeurd jaarverslag, inclusief winst-en-verliesrekening, beschikbaar moeten worden gesteld door de bedrijven.

Daaraan moet worden toegevoegd dat ook het financiële toezicht sterk verbeterd moet worden. Uit de eerder aangehaalde reactie van staatssecretaris Martin van Rijn blijkt dat van enige consistentie momenteel geen sprake is. De staatssecretaris verwijst naar de IGZ als een orgaan dat financieel toezicht houdt (www. rijksoverheid.nl, 2016, 2). Bij ons weten is de IGZ vooral geschikt om op te treden als medisch toezichthouder en niet als financieel toezichthouder. De IGZ toetst, met andere woorden, op medische misstanden, maar niet op financiële misstanden. Ook de NZa heeft het financiële toezicht niet als een belangrijke taakopdracht. De NZA ziet toe op het op correcte wijze aanleveren van declaraties door zorgaanbieders, maar onderzoekt niet of de onderliggende gegevens voor de declaraties gebaseerd zijn op oneigenlijk gebruik van zorggelden, zoals de staatssecretaris zelf vermeldt (www.rijksoverheid.nl, 2016, 5). Hij verwijst ook naar de raden van roezicht waarover zorgbedrijven volgens de Wet toezicht zorginstellingen moeten beschikken. Over de bemensing en het functioneren van deze raden is weinig bekend. Uit een niet-representatief onderzoek bij een aantal kleine zorgaanbieders blijkt dat familieleden en kennissen deel uitmaken van de raden. Het is zeer kwestieus of hiermee onafhankelijk toezicht gewaarborgd is.

Ten slotte verwijst de staatssecretaris naar de inkopende partijen (zorgverzekeraars, zorgkantoren en gemeenten) als verantwoordelijk voor het financiële toezicht op de zorgaanbieders. Na de decentralisatie van een groot deel van de langdurige zorg naar de gemeenten in 2015 hebben gemeenten er veel belang bij de kwaliteit en de besteding van de door hen uitgekeerde zorggelden te controleren. Gemeenten zullen hier expertise over moeten opbouwen. De wijze van verantwoording door de zorgaanbieders en de controle daarop door gemeenten moet echter nog vorm krijgen en het is nog te vroeg om te concluderen dat gemeenten op deze controletaak berekend zijn. De gegevens voor 2015 (het eerste jaar van de decentralisatie) laten zien dat er wat betreft de verslaglegging en de winstgevendheid van zorginstellingen nog weinig veranderd is.

Centraal toezicht op en controle van het financiële handelen van zorgbedrijven blijven voorlopig nodig, maar zijn verwaterd doordat deze taken verdeeld zijn over diverse instanties. Wij zouden daarom willen pleiten voor één centraal controleorgaan dat exclusief op rijksniveau de financiële praktijk van de zorgbedrijven monitort. Hierbij is samenwerking en/of coördinatie met de gemeenten (en, zo nodig, zorgkantoren en zorgverzekeraars) gewenst. Het zou bijvoorbeeld mogelijk moeten zijn dat gemeenten vermoedens van fraude en/of valsheid in geschrifte bij het centraal toezicht meldt, waarna dit orgaan kan besluiten tot een fraudeonderzoek bij het desbetreffende zorgbedrijf. Het zou de administratieve last van de gemeenten bij het toezicht op de zorgaanbieders beperken, zodat zij meer bestuurlijke energie kunnen steken in de vormgeving van contracten met de zorgaanbieders, waarbij vooral de financiële en de zorginhoudelijke verantwoording door de zorgaanbieders een prominente plaats behoren te krijgen. 


\section{Noten}

1 De zorgkosten voor deze mensen werden voor het grootste deel uit de AWBZ gefinancierd. De volksverzekering AWBZ dekte tot 1 januari 2015 het leeuwendeel van de kosten voor niet individueel verzekerbare ziektekostenrisico's. Daarna is de niet-ziekenhuisverpleging de verantwoordelijkheid van de gemeenten geworden.

2 Het gaat hier onder andere om de bedrijven Boriz B.V. te Velp en de stichting Alliade te Heerenveen; zie www.rijksoverheid.nl/.

3 Zorgondernemingen kunnen in meerdere segmenten actief zijn, vooral wanneer het ziekenhuizen ( $\mathrm{KKH})$, revalidatiecentra (RVC) en zelfbehandelcentra (ZBC) betreft. Omdat er geen financiële informatie op segmentniveau beschikbaar is, zijn ziekenhuizen, revalidatiecentra en zelfbehandelcentra niet toegewezen aan de segmenten GGZ, MOVO, GHZ, VVT, kraamzorg en jeugdzorg, maar zijn deze als afzonderlijke segmenten in de analyse meegenomen. Zorgondernemingen die actief zijn binnen meerdere segmenten uit GGZ, MOVO, GHZ, VVT, kraamzorg en jeugdzorg zijn toegewezen aan het segment overig (OVG).

4 In de praktijk blijkt het uitkeren van dividend nog wel eens gebruikt te worden als een methode om de wet op de topinkomens te omzeilen.

5 Een redelijk aantal verlieslijdende zorgbedrijven met een negatief eigen vermogen worden in stand gehouden door de vreemdvermogenverschaffers. Waarom dit gebeurt, is niet duidelijk; de financiële prestaties lijken dit niet te rechtvaardigen.

6 Een alternatieve manier om de schaalvoordelen te onderzoeken is te kijken naar de ratio omzet/personeelskosten, omdat personeelskosten een belangrijke factor zijn in het genereren van omzet. Echter, personeelskosten worden niet eenduidig gerapporteerd, vooral de kosten van externe inhuur niet. Er zijn ondernemingen die dit als kostprijs van de omzet of als overige kosten rapporteren. Dit maakt een crosssectionele vergelijking weinig inzichtelijk.

7 Overigens zijn aan stichtingen soms bv's gelinkt die in opdracht van de stichting zorgtaken uitvoeren, Zie bijvoorbeeld de reconstructie www.rtlnieuws.nl/nieuws/ reconstructie-dit-ging-vooraf-aan-de-alliade-onthulling, die de stichting Alliade betreft. In dergelijke gevallen kan het winstmotief indirect alsnog een rol spelen.

8 Een ander opvallend element is dat ook bij stichtingen financiële transacties plaats kunnen vinden die tot curieuze resultaten kunnen leiden. Zo zijn in tabel 4a drie stichtingen opgenomen die dankzij niet nader gespecificeerde overboekingen winsten boeken die groter zijn dan de omzet.

9 Zie www.kvk.nl/inschrijven-en-wijzigen/deponeren/deponeren-jaarrekening/welkegegevens-moet-u-in-de-jaarrekening-opnemen/.

10 Soms wordt dit expliciet vermeld; in andere gevallen staat op hetzelfde adres als de stichting ook een bv ingeschreven bij de Kamer van Koophandel.

\section{Literatuur}

De Nederlandsche Bank (2006). Winstgevendheid Nederlandse bedrijven: goede conditie na financieel moeilijke periode. DNB kwartaalbericht, september. 
Douven, R., Remmerswaal, M., \& Zoutenbier, R., (2016). Gedragsreacties van ggz-aanbieders op financiële prikkels. ESB, 18 februari: 134-137.

EY (2016). Barometer Nederlandse Gezondheidszorg 2016 (Transitie zorgsector zet druk op financiële performance). www.ey.com/nl/nl/industries/health/ey-barometernederlandse-gezondheidszorg-2016.

wetten.overheid.nl/BWBR0018983/2015-05-30, geraadpleegd in september 2016. www.jaarverslagenzorg.nl/, geraadpleegd in juni 2016.

www.rijksoverheid.nl/documenten/kamerstukken/2016/09/12/beantwoordingkamervragen-over-fraude-bij-zorgorganisatie-boriz, geraadpleegd in juni 2016. www.rijksoverheid.nl/regering/inhoud/bewindspersonen/martin-van-rijn/documenten/ kamerstukken/2016/08/05/kamerbrief-over-conclusies-en-vervolg-onderzoekenalliade, geraadpleegd in augustus 2016. 